\title{
RECOGNITION OF OPPORTUNITY FOR INTERNATIONALIZATION IN THE SUB- SAHARA AFRICA: AN ATTENTION-BASED PERSPECTIVE
}

\author{
By
}

\author{
Inioluwa Bankole
}

Bachelor of Commerce, Saint Mary's University, Halifax, 2017

\author{
A thesis presented to Ryerson University \\ in partial fulfillment of the requirements for the degree of \\ Master of Science in Management \\ in the program of \\ Master of Science in Management
}

Toronto, Ontario, Canada, 2020

(C) Inioluwa Bankole, 2020 


\section{AUTHOR'S DECLARATION}

I hereby declare that I am the sole author of this thesis. This is a true copy of the thesis, including any required final revisions, as accepted by my examiners.

I authorize Ryerson University to lend this thesis to other institutions or individuals for the purpose of scholarly research.

I further authorize Ryerson University to reproduce this thesis by photocopying or by other means, in total or in part, at the request of other institutions or individuals for the purpose of scholarly research.

I understand that my thesis may be made electronically available to the public. 


\begin{abstract}
Title: Recognition of opportunity for internationalization in Sub-Saharan Africa: An attentionbased perspective

Name: Inioluwa Bankole

Degree: Master of Science in Management

Program: Master of Science (Global Management Studies)

University: Ryerson University

Year: 2020

Sub-Saharan Africa (SSA) is home to six of the top ten fastest-growing economies in the world.

Despite this strong performance, Canadian firms have a limited presence in SSA. International business studies suggest that global expansion of firms into foreign markets is possible when firms have solid access to international networks, familiar market institutions, and senior managers with international experience. By analyzing several cases, grounded in an attentionbased perspective, this study aims to answer 1) how senior managers' attention processes enable opportunity recognition in SSA and 2) how they translate the recognized business opportunity into global expansion in SSA. This thesis uses qualitative research in which interviews were conducted with staff from seven companies that internationalized into SSA. The key findings show that senior managers' initial motivations to expand into and their categorization of the SSA market impacted opportunity recognition for global expansion.
\end{abstract}




\section{ACKNOWLEDGEMENTS}

First and foremost, all praise and thanks to Almighty God in whom I do that which I do.

A special thank you to Dr. Horatio Morgan and Dr. Sui Sui, my supervisors for this thesis. You have shaped me into a strong academic. Thank you for your guidance, encouragement and support from my very first day to today. I am forever grateful for your thoughtful recommendations and feedback.

Thank you Dr. Kalu and Dr. Okafor for serving on my examination committee. Your wisdom has been helpful in refining my research. Thank you also to all TRSM faculty and admin members for your help and guidance in my overall experience here at Ryerson University.

My completion of this project could not have been possible without the amazing business leaders who share the same passion for Canada and Africa and contributed time out of their busy schedule to consult with me on this project.

Finally, to my tribe and support system I thank you for your endless support and encouragement. I couldn't have done this without your help. It really takes a village. 


\section{TABLE OF CONTENTS}

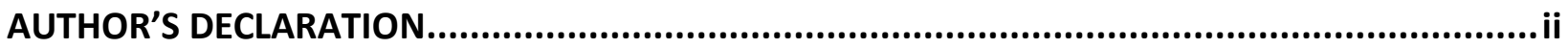

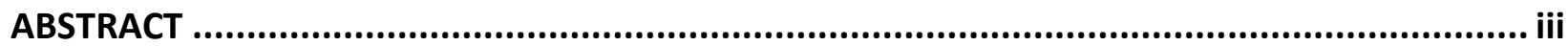

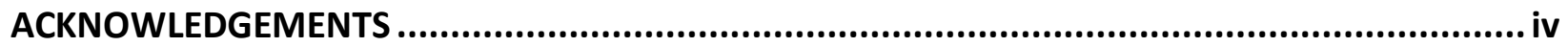

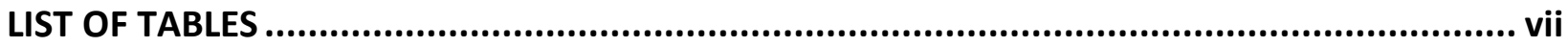

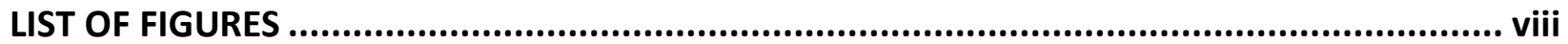

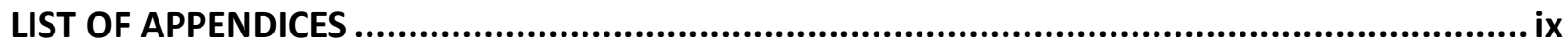

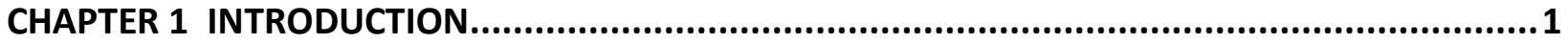

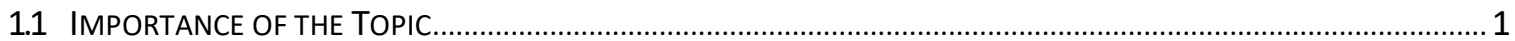

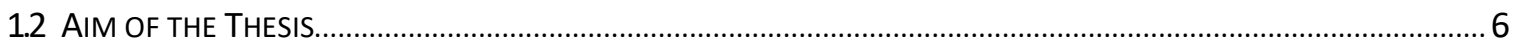

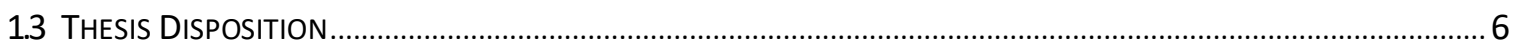

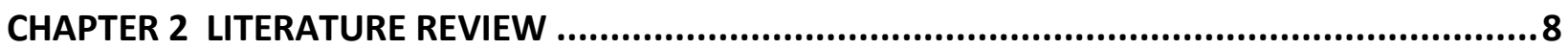

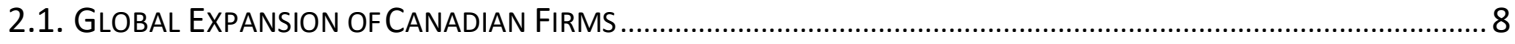

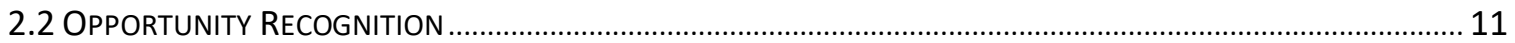

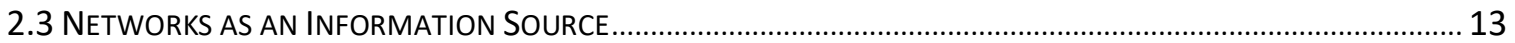

2.4 FoCUS ON DISTANT MARKETS: SUB-SAHARAN AFRICA AS A RESEARCH CONTEXT ......................................... 14

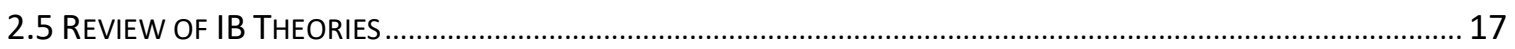

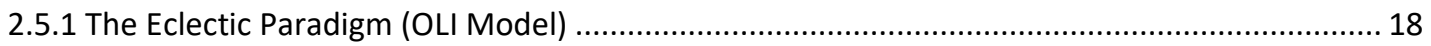

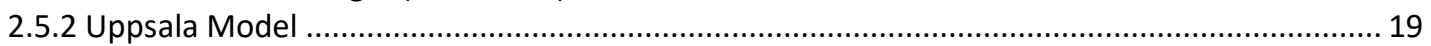

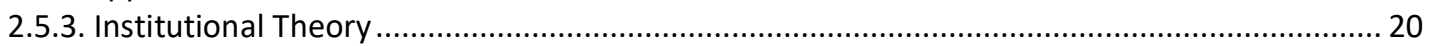

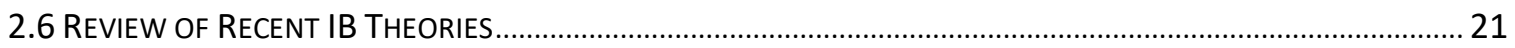

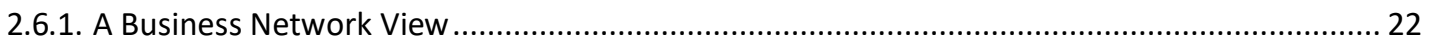

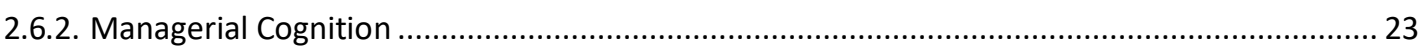

2.7 THEORETICAL FRAMEWORK: AN ATTENTION-BASED VIEW OF INTERNATIONALIZATION IN DISTANTMARKETS

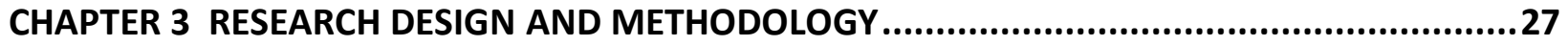

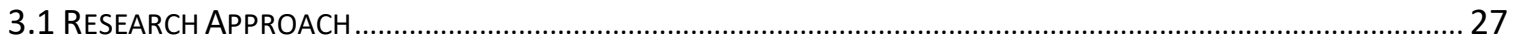

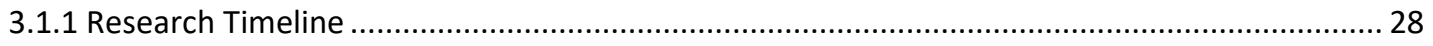

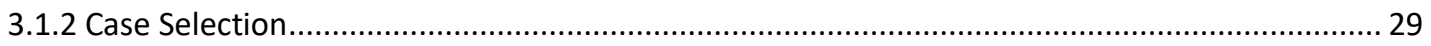

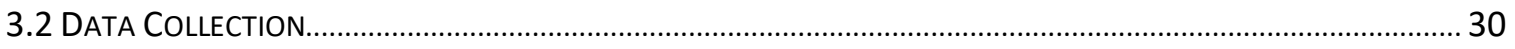

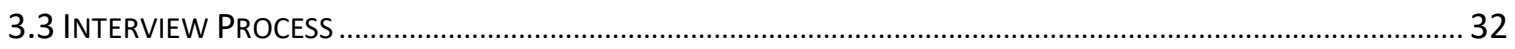

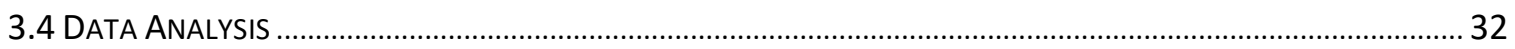

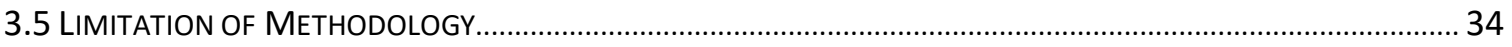

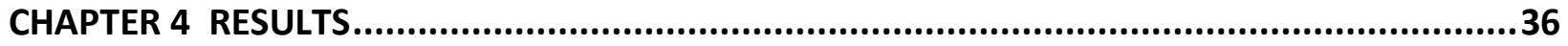

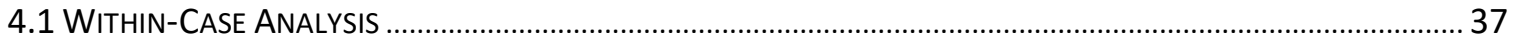

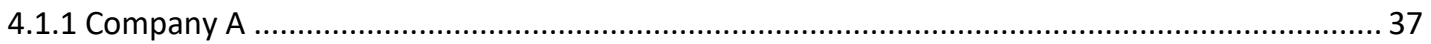

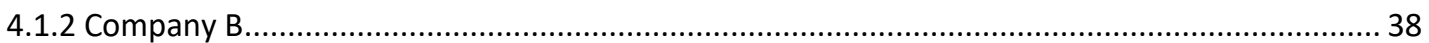

4.1.3 Company C

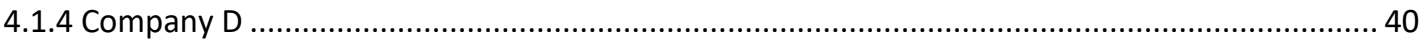




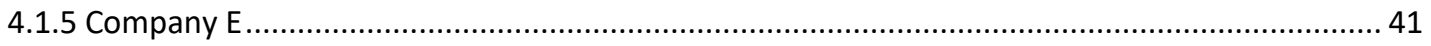

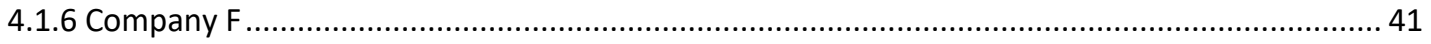

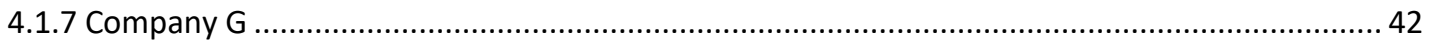

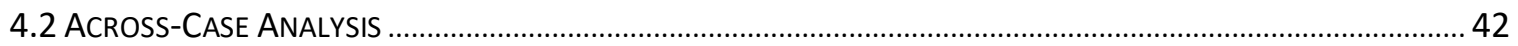

4.2.1 Pre-Noticing Phase (Initial Expectations, Categorization and Motivation) ............................... 43

4.2.2 Salience and Accessibility of Networks and Sources of Information .................................... 44

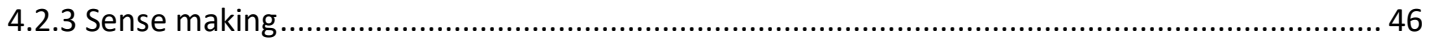

4.2.4 Perceived Value and Quality of Opportunity Recognition ................................................. 47

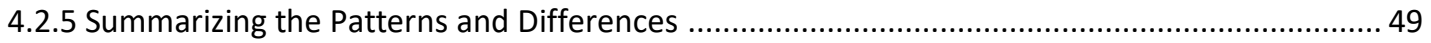

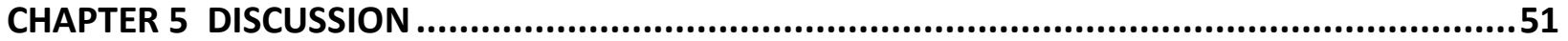

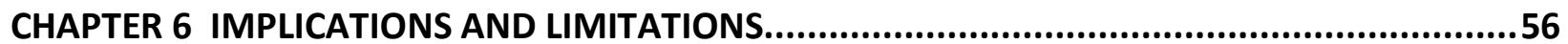

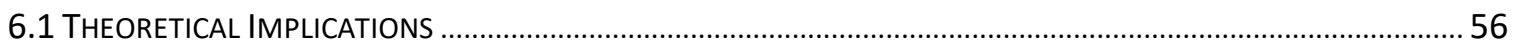

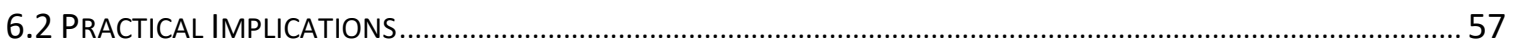

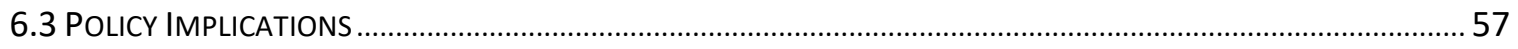

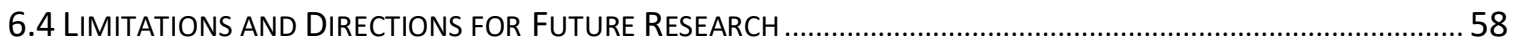

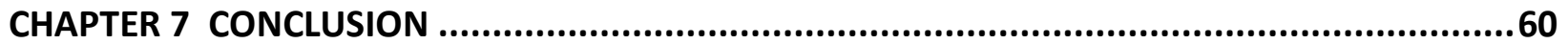

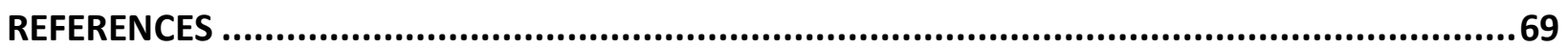




\section{LIST OF TABLES}

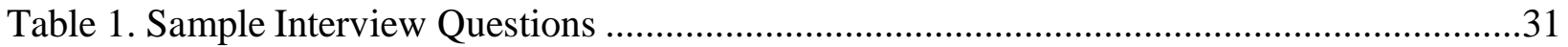

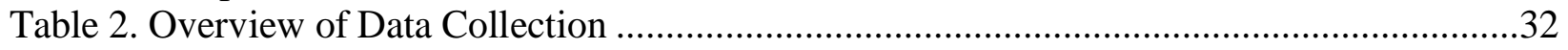

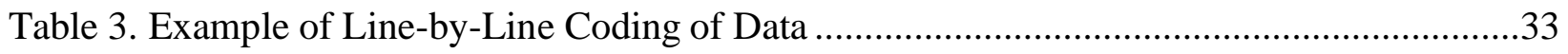

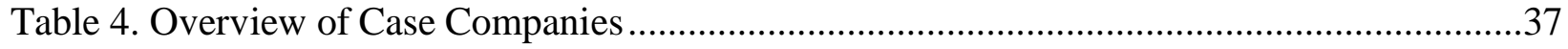

Table 5. Patterns and Differences among Case Companies ......................................................50 


\section{LIST OF FIGURES}

Figure 1. Canadian Majority-Owned Foreign Affiliate Sales by Region (2013-2017)................10

Figure 2. Canadian Direct Investment Abroad by Region (2013-2017) .................................11

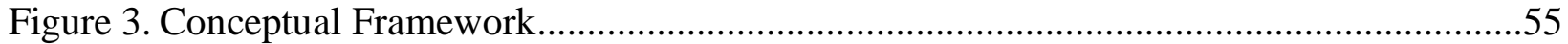




\section{LIST OF APPENDICES}

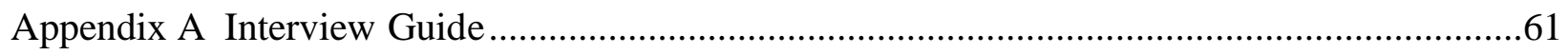

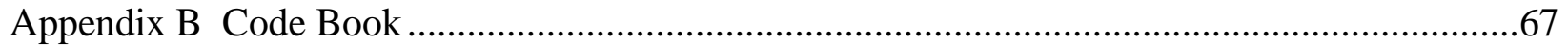




\section{CHAPTER 1 INTRODUCTION}

\subsection{Importance of the Topic}

The sub-Saharan African (SSA) market is a 1.2 billion-person market on the cusp of transformative growth. Its gross domestic product (GDP) is rising faster than the rest of the world at an annual growth rate of 3.6 percent, which is 1.6 percent higher than the world's average growth rate as of 2019 (World Bank, 2019). It is also home to six of the top 10 fastest growing economies in the world, which have outpaced both China and the United States (IMF, 2019; Leke et al., 2010). In addition to this strong growth performance, the SSA market is becoming increasingly appealing to foreign investors because of ongoing improvements in the institutional environment-from reduced macroeconomic instability (i.e., declining inflation rates) to reduced political instability and increased ease of doing business (IMF, 2019). In contrast to developed economies, SSA countries also have a young and fast-growing population with a median age of 19, which can foster and sustain future growth (Business Council Canada, 2019; Leke et al., 2010).

These observations suggest that the SSA market has opportunities worth exploring. Yet Canadian firms appear to be foregoing these opportunities, given their limited presence in this market. For example, Canadian banks could market their world-leading online banking expertise in Kenya and capitalize on its remarkable advances in mobile phone banking (Monks, 2017). However, since Canadian banks' international operations are primarily concentrated in the US and the Americas (Monga, 2018), they are failing to tap into Kenya's attractive financial market. Also, Canadian software companies could exploit time differences between SSA countries and Canada by setting up branch offices in SSA countries to increase productivity and double 
Workdays (Kielburger, 2017). The missed opportunities are also apparent in Canada's trade diversification efforts, which remain largely focused on Asia-Pacific and North America. This is consistent with the finding that the value of Canada's exports to SSA was less than one percent of the value of its global exports in 2018 (Global Affairs Canada, 2019). Recent economic analysis by the Business Council of Canada (2019) suggests that if Canada seized opportunities in Africa, the value of its exports could reach USD 6.6 billion by 2030, which would translate into a potential gain of USD 4.1 billion over the next decade.

Although Canadian firms should be looking to SSA for new growth possibilities, I am mindful that there are real challenges and risks that can get in the way of senior managers recognizing opportunities in distant markets like SSA. Some of these challenges include poor infrastructure, political instability in some regions of the continent and weak institutions. Other risks in the market include a sharp rise in risk premiums. This tightening of global conditions could add to financial and fiscal stress in SSA, making it difficult for senior managers to investigate the SSA market (IMF, 2019). Furthermore, the region faces immense development challenges such as reducing public debt, improving public financial management and reinvigorating credit growth. These factors make it challenging for firms to expand into SSA. However, for firms to tap into the SSA market, they must be willing to take the extra step in developing strategies to mitigate these risks (IMF, 2019).

These challenges and risks highlight the need for strategies that can help Canadian firms overcome, or at least, cope with them. Firms must develop a SSA market strategy specific to the needs of that market. At the same time, becoming too preoccupied with these challenges and risks could mean overlooking the opportunities that could be exploited in a manageable way as some multinationals from regions such as China and the US are already doing profitably (Leke et 
al., 2018). Therefore, it is important to look at how Canadian firms could tap into the SSA market for new opportunities and global expansion.

Various international business (IB) theories provide a starting point for exploring how Western firms recognize the opportunities that underpin the variations in their patterns of global expansion. According to the liability of foreignness perspective, a firm's global expansion depends on the relative ease of identifying opportunities in a foreign market (Zaheer, 1995). Specifically, firms are in a better position to identify opportunities when they operate in familiar markets. However, they often find themselves in situations where they encounter few familiar foreign markets. Foreign markets, such as SSA countries, are unfamiliar because they are geographically (or physically) distant and institutionally dissimilar (i.e., they possess different schemes, rules and norms of business operations from the home market) relative to the North American market (i.e., Canada and the US) (Zaheer, 1995). As a result, Western firms are prone to avoiding the additional costs or difficulty of operating in SSA countries, focusing instead on geographically closer and institutionally similar countries.

A network perspective adds to these insights by suggesting that the most serious form of liability comes from outsidership (Hohenthal et al., 2015; Johanson \& Vahlne, 2009; Zhou et al., 2007). According to this perspective, firms risk liability of outsidership when they lack access to interfirm networks that can provide critical market information for global expansion, making it difficult for them to develop the capabilities required to identify and exploit opportunities in a geographically or institutional distant market (Johanson \& Vahlne, 2009). Firms in North America, and Canada in particular, might want to reduce their liability of outsidership by foregoing opportunities in geographically and institutionally distant foreign markets such as SSA countries. 
A managerial cognition perspective complements these insights by focusing on the role of senior managers in the global expansion of their firms. According to this perspective, senior managers are tasked with making critical decisions on firm expansion. However, due to the complexities, ambiguity and uncertainty present in those decisions, they tend to draw on preexisting mental models (i.e., simplified knowledge structures or experience to make such decisions) (Eggers \& Kaplan, 2013; Maitland \& Sammartino, 2015). However, senior managers without previous experience in a particular foreign market may lack the requisite mental models, and hence, would find it difficult to make sense of differences in that environment or overcome the additional cost of conducting business in this environment (Baron \& Ensley, 2006; Javalgi \& Todd, 2011). In these circumstances, Canadian senior managers would be at a cognitive disadvantage (i.e., lack the requisite mental model) in less familiar markets such as SSA countries and would be inclined to forego or overlook opportunities in them.

Although these theoretical lenses provide helpful insights into the global expansion of firms, we do not have a deep understanding of how senior managers recognize opportunities in institutionally distant markets. The liability of foreignness and outsidership provide helpful insights into the adverse implications of geographic and institutional distance when firms internationalize. Additionally, the managerial cognition perspective adds complementary insights by clarifying the role senior managers play in the global expansion of their firms and the recognition of opportunity. However, there needs to be an integration of these insights in a way that clarifies more precisely how senior managers can recognize opportunities in the SSA context. While we have insights into global expansion after the market opportunity has been recognized, we have only a limited understanding of how senior managers initially recognize opportunities for global expansion, particularly in the SSA context. 
To fill this gap, I explore how senior managers in Canadian firms recognize opportunities in the geographically and institutionally distant foreign market, SSA countries. I develop a conceptual framework to address this issue by drawing on an attention-based perspective, along with a case study analysis. According to the attention-based perspective, senior managers play a crucial role in the recognition of opportunity because they find themselves in situations that affect what they know, who they know and what they do (Ocasio, 1997, 2011; Rhee \& Leonardi, 2018). A key implication is that senior managers' ability to recognize opportunities in SSA countries depends on their attention processes in the context of their networks (Rhee \& Leonardi, 2018). They would be in a better position to recognize opportunities in SSA countries if they had a network of diverse contacts with ties to these countries (e.g., employees with social ties in SSA countries). This means that they need to recognize their need for such contacts and become more aware of them. Hence, we need to have a deep understanding of factors that influence why some senior managers are more aware of their need for a network of diverse contacts or become more aware of such contacts, than others.

To shed light on these issues and add to the conventional attention-based perspective, I conduct a case study analysis. I explore various themes to clarify the attention processes of senior managers in recognizing opportunities in SSA countries. Based on this case analysis, I build on and extend a conceptual model of attention processes in senior managers. My model adds nuanced insights by clarifying why and how senior managers' ability to recognize opportunities in geographically and institutionally distant markets like SSA countries depends on their initial reasons for global expansion, initial categorization of the SSA market, and the salience of information cues they receive from network contacts. 


\subsection{Aim of the Thesis}

The role of senior managers in recognizing opportunities for global expansion is limited. In light of this, this thesis aims to provide a socio-cognitive perspective to increase the understanding of how senior managers recognize an opportunity in foreign markets, especially distant markets like SSA. To investigate this process, I ask the following questions:

1. How do senior organizational managers' attention processes enable opportunity recognition in SSA countries?

2. How do senior organizational managers translate the recognized business opportunity into global expansion activities in SSA countries?

\subsection{Thesis Disposition}

Chapter 2 Literature Review: This chapter covers literature on existing IB theories, recent IB theories and the attention-based perspective. After analyzing and synthesizing the information, I present a conceptual model. The model will include the key concepts in the literature and tie them together to answer the research questions.

Chapter 3 Methodology: In this chapter, I explain how I conducted the study, why I conducted it in the way I did and how I draw conclusions from the findings. Also, I address the limitations of the methodology and how they have been accounted for.

Chapter 4 Findings: This chapter presents an overview of the case companies that operate in the SSA market. A brief history of each case is presented in tabular form with specific identifications relevant to the research questions.

Chapter 5 Analysis: This chapter presents and analyzes the findings in light of the framework in which this study was conducted. 
Chapter 6 Implications and Limitations: This chapter discusses the implications of the research for theoretical development, policy and managerial decisions. The chapter also discusses the limitations of this study based on various factors such as scope and time.

Chapter 7 Conclusion: This chapter concludes by providing answers to the research questions, building on the existing literature, laying out implications for senior managers and proposing topics for future study in the field. 


\section{CHAPTER 2 LITERATURE REVIEW}

Global firm expansion has been widely studied in international business literature, and various scholars have discussed how companies move beyond their home markets to host markets. This phenomenon is an important process in the life span of a company (Johanson \& Vahlne, 1977, 1990, 2003, 2006, 2009). Global expansion not only enables companies to expand beyond their borders, it enables a "learning by doing" process that increases the international operation of a firm. The process is multi-faceted and differs from industry to industry; between product to process intensive firms; and market institutions (Figueira-de-Lemos \& Hadjikhani, 2014).

\subsection{Global Expansion of Canadian Firms}

Over the past century, the Canadian economy has grown from local servicing of goods and services to a more complex and interconnected system of doing business. Canadian multinational corporations (MNCs) have sought opportunities in foreign markets through exports and foreign direct investment (FDI) activities to expand beyond Canada's borders.

The Canadian economy grew by 1.9 percent in 2018, a positive increase from 2017, while exports of goods and services globally increased by 6.2 percent, imports by 5.4 percent, and FIDs by 70 percent in 2018 (Statistics Canada, 2015, 2019). Canadian investment abroad (CDIA) fell by 38 percent mostly due to ongoing trade tensions that lowered investment in the US (Global Affairs Canada, 2019).

According to the International Institute for Management Development's (IMD) world competitiveness ranking, in 2019 Canada ranked 13th out of 63 countries in overall 
competitiveness, the worst performance in the survey's history, which goes back to 1997 (IMD, 2019).

Canada's international trade activities have been fostered through various trade deals like the North American Free Trade Agreement (NAFTA) and Trans-Pacific Partnership (TPP). However, Canadian international business activities have historically been concentrated in North America, Europe and now recently the Asia-Pacific region (Global Affairs Canada, 2019).

While economic theory states that export activities will gravitate to large markets, there is a benefit to exporting to emerging economies especially before their growth. The Canadian economy would benefit from diversifying its international trade activities not only into more regions but specifically into fast-growing emerging markets (Global Affairs Canada, 2019).

In line with the intent of this thesis, it is important to briefly review Canada's relationship with SSA. Canada has cultivated relationships with SSA for more than five decades through peacekeeping missions establishing democracy. Canada is also as a huge player in natural resources and mining on the continent. However, given the political instability and poverty of SSA, Canada's priorities in SSA has largely focused on developmental aid. Africa remains the highest recipient of Canadian international assistance at 39 percent of its total budgeted assistance (Black et al., 1996; Canadian International Development Platform, 2019).

Recent Statistics Canada data shows that majority-owned foreign affiliate sales remain low for Africa compared to other regions. Figure 1 reveals the distribution of Canadian majorityowned affiliate sales by region for the years 2013 to 2017 in million dollars. Canadian multinationals typically expand their activities across national borders through exports and sales by foreign affiliates. These sales include those made to foreign markets or in Canada. As shown in Figure 1, affiliate sales are higher for North America and the Caribbean compared to other regions; they are exceptionally low for Africa. 
Figure 1. Canadian Majority-Owned Foreign Affiliate Sales by Region (2013-2017)

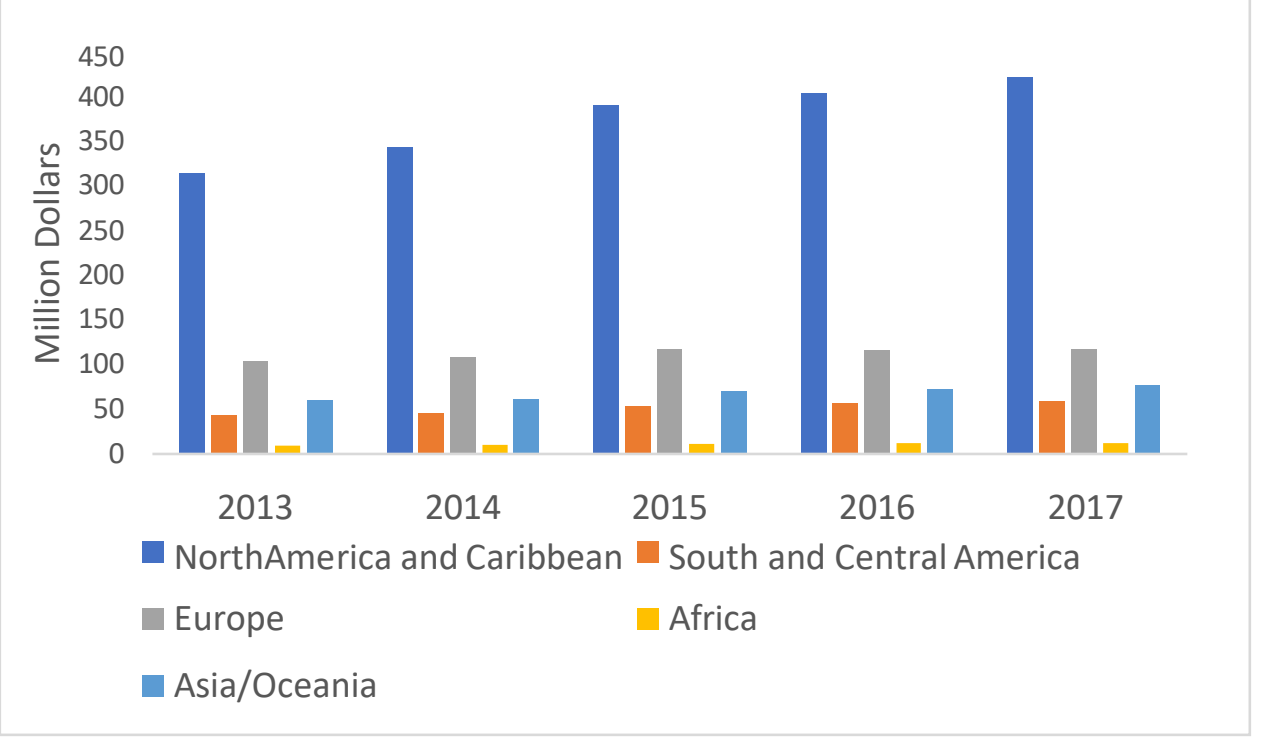

Source: Statistics Canada (2019) Table 36-10-0470-01

Global expansion activities present themselves in various forms (i.e., outward and inward FDIs, greenfield entry, mergers and acquisitions, etc.) While studies of Canadian multinationals operating abroad are few, these outward investments remain highly concentrated in the US and Europe and are significantly lower for Africa (see Figure 2). The major driver of global expansion in Canadian firms is FDIs. FDIs can be in the form of direct investment in an enterprise, a Canadian direct investment abroad (CDIA) outward FDI or a direct investment enterprise with foreign direct investment (inward FDI). These FDIs are largely based on immediate investment (Statistics Canada, 2017). 
Figure 2. Canadian Direct Investment Abroad by Region (2013-2017)

800,000

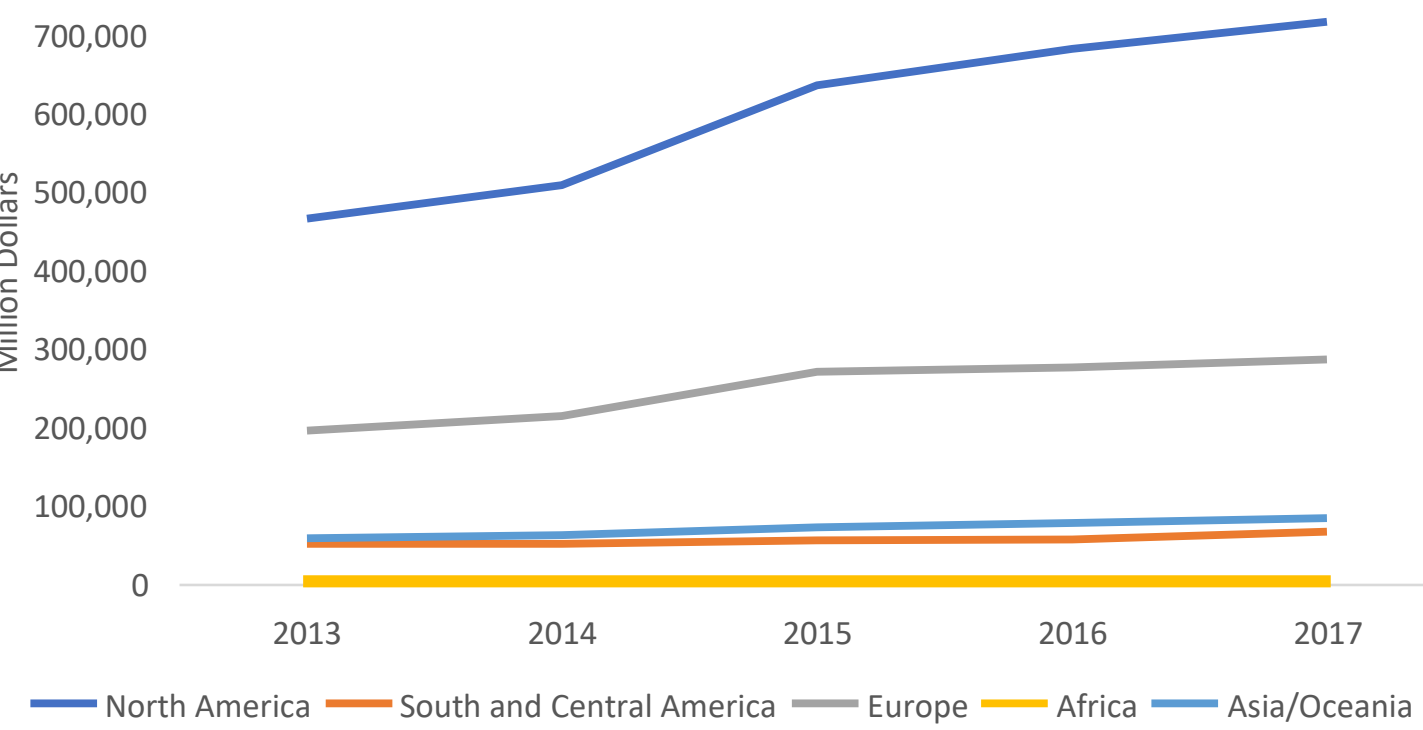

Source: Statistics Canada (2019), Table 36-10-0008-01

The Canadian economy is an open economy, although relatively small, and expanding into other markets is critical for it to compete and grow. Based on Figure 2, Canadian firms typically expand into similar markets in North America and Europe rather than into the SSA market. However, to discover opportunities in distant markets like SSA, Canadian global expansion activities need to move beyond Canada to markets that are distant and present opportunities for exponential growth. Also, with recent trade agreements being renegotiated (NAFTA and BREXIT), the Canadian economy needs to diversify its international business portfolio and expand into other markets, like SSA.

\subsection{Opportunity Recognition}

Identifying and selecting the right opportunity is an important ability for senior managers to possess as recognizing market opportunity is a key aspect of internationalization (Ardichvili et al., 2003; Stevenson et al., 1985; Venkataraman, 1997). Opportunity recognition is the ability to identify instances in which new markets, goods and services can be introduced to present new 
means of doing things (Ardichvili et al., 2003). It is a cognitive process of pattern recognition through which individuals identify and select the right opportunities for new ventures to generate global opportunities for the firm (Baron \& Ensley, 2006; Sigrist, 1999).

Internationalization requires a successful opportunity development process (Ardichvili et al., 2003). Scholars have argued that there are distinctive cognitive processes and personality traits like creativity and optimism that contribute to recognizing opportunities (Phillips \& Tracey, 2007; Sigrist, 1999). However, various factors affect senior managers' ability to recognize opportunities. Such factors include entrepreneurial alertness (i.e., cognitive capability that impacts awareness of new possibilities), prior knowledge of market and social networks (Ardichivili et al., 2003; Ozgen \& Baron, 2007).

Ardichvili et al. (2003) posit that the term “opportunity recognition” can be misleading as it connotes that opportunities are lying around waiting to be found, whereas in reality, pursuing opportunities requires creativity and must be developed and evaluated, that is, opportunity recognition is a process that is continuous and proactive and dependent on the perception of the external market environment and the interpretation of events, changes and trends in it.

Discovering a new market opportunity is fundamental for global expansion as it presents new opportunities for firm growth in terms of productivity, increased global presence and profitability. It also facilitates economic growth of both host and home markets (Gordon, 2011). Hence, for firms to expand beyond their home market, a market opportunity must be noticed, and expansion must be backed with relevant information from networks that can inform global decisions about moving into new markets (Kontinen \& Ojala, 2011).

Recognizing opportunities in a market is preceded by sense-making (i.e., the ability to interpret information in a way that is understood) by senior managers to develop the opportunity in a distant market and capture the opportunities present in it (Ardichivili et al., 2003; Baron \& 
Ensley, 2006). As mentioned earlier, recognizing opportunities is critical to global expansion. However, recognizing opportunities in unfamiliar markets can be difficult as opportunities could be constrained by market institutions, lack of access to networks and insufficient information about unfamiliar markets (Johansson \& Vahlne, 2003; Zahra et al., 2005). This implies there is a need to clarify and deepen our understanding of how senior managers recognize opportunities in unfamilliar and distant markets, especially one like SSA.

\subsection{Networks as an Information Source}

The role of networks has also been widely studied in international entrepreneurship (IE) and IB research. Studies have looked at the role of networks in internationalization speed, senior management team advice networks and their impact in internationalization (Athanassiou \& Nigh, 1999; Johansson \& Vahlne, 2003; Musteen et al., 2010). Studies of social capital theory and IE literature show that companies that are able to tap into their networks to overcome resource constraints typically overcome market difficulties (Lew et al., 2013).

Networks serve as a conduit for information (Owen-Smith \& Powell, 2004). Hence, the information an organization has is significantly related to the networks of the organization as well as the senior managers' networks. Consequently, senior managers form unique advice networks to share tacit knowledge about IB and IE activities. Athanassiou and Nigh (1999) examined the internationalization extent of a firm (i.e., the degree to which the firm is present in international markets) and found that senior managers have to expand their knowledge to cope with the increased demand of a new market. Hence, they depend on the advice network density of the firm.

The structure of a network also influences the breadth of knowledge that senior managers access within their network (Burt, 1992), as networks provide critical and private information 
that senior managers might not be privy to if their primary source of information is media, books and the internet (Hohenthal et al., 2015; Kontinen \& Ojala, 2011; Zhou et al., 2007).

As firms expand into new markets, networks remain a critical source of information for global expansion. However, as firms expand into markets that are unfamiliar, especially ones that are geographically and physically distant, senior managers' access to networks is critical to gain information that enables their opportunity recognition for global expansion.

Despite theoretical and empirical support for how networks influence global expansion, there is a lack of clarity on how senior managers recognize their need for a network of diverse contacts that can provide critical information for global expansion. This thesis examines this phenomenon critically by looking at the types of networks senior managers access and how they decide what information to attend to and what information to ignore.

\subsection{Focus on Distant Markets: Sub-Saharan Africa as a Research Context}

There are several reasons why I focus on SSA as a distant market. However, the term "subSaharan Africa" needs to be examined briefly. The term is problematic as Africa is a large continent comprising various countries that differ geographically and culturally. While this grouping has been relied upon to sort data and assign aid, "sub-Saharan" is too broad a term to reveal the intricacies that are present in the various countries on the continent, and this phrase strengthens an imaginary divide between northern Arab countries and the rest of Africa (de Haldevang, 2016). Also, academics and the rest of the world are used to speaking about Africa as one country which further complicates the term. That being said, for this study, "sub-Saharan Africa" will be used for its simplicity and ease of classification of non-Arab-speaking African countries, which were primarily colonized by Britain, France, Spain and Portugal. 
Africa is 11 million square miles larger than China, Europe and the US combined and has over $\$ 1.4$ trillion more in consumer spending than India. It also has over 400 companies with revenues over $\$ 1$ billion (Leke et al., 2018). The economy has a steady GDP growth rate and a young population, with an average age of 19. It exceeds China and Canada in its future propensity to maintain a sustainable young economy (Leke et al., 2018; World Bank, 2019). Also, the technology revolution sweeping across SSA is evident in the mobile banking sector, with early adoption and innovation in the digital industry (Monga, 2018). The income per capita of Africa's cities is also higher than the continental average making them an attractive market (IMF, 2019; Leke et al., 2018).

The SSA is valuable not just because it is an understudied geographic region, but because of the institutional dissimilarities of its markets (i.e., the extent of similarity and dissimilarity between the regulative, cognitive and normative institutions of two countries) and institutional factors present in the market that further our understanding of the critical factors that contribute to global expansion into distant market (Xu \& Shenkar, 2002). Institutional dissimilarity is derived from institutional theory, a perspective in which the institutional environment is seen as a key determinant of firm structure and behaviour (DiMaggio \& Powell, 1991; Xu \& Shenkar, 2002).

Following the signing of the African Continental Free Trade Agreement (ACFTA) on March 21, 2018, measures were implemented to integrate the African economy with the world by improving cross-border transit of goods and services in SSA countries. Additionally, with SSA's growing population and GDP, increased global opportunities are forecasted. However, despite these economic opportunities on the continent, Canadian firms have a limited presence in the SSA market; they are missing out on market opportunities. This could be as the result of their 
inaccurate perceptions of the economic outlook of the continent coupled with the realities of international business activities in the region.

According to the Government of Canada, Canada's priorities for SSA include the following: "providing development assistance," "promoting democracy," "promoting peace and security" and "increasing commercial and economic ties" (Global Affairs Canada, 2020). While Canada has contributed to the continent through the provision of foreign aid, peacekeeping missions and healthcare initiatives, this posture towards the SSA creates a perception bias about its market that systematically sidelines SSA as a potential place to do business. This neglect is revealed in Canadian firms' heavy dependence on the US for over 80 percent of Canada's exports and a trade diversification discussion that is largely focused on the Asia-Pacific region (Business Council Canada, 2019; Global Affairs Canada, 2019).

Canada heavily depends on the US market for a large portion of its trade activities, thus creating a risk-averse economy and complacent trade strategy, given the trade tension between the US and China (IMD, 2017). While the SSA market is not an easy place to do business because of the difficult institutional factors such as infrastructure gaps, economic and political volatility and geographic complexity, Canadian companies' inability to see Africa as more than an "aid receiving" or "politically instable" region prevents senior managers from recognizing the potential of the African economy especially with recent development in countries like Rwanda, Ethiopia and Ghana that have become more politically stable and peaceful, and have increased the ease of doing business (World Bank, 2019). The macroeconomic outlook for SSA continues to strengthen, which reflects a more supportive external environment and steady growth in the global economy (IMF, 2019).

Take China as an example. It has moved steadily but speedily into parts of SSA, and trade between the two has increased by 400 percent since 2000 . China has invested heavily in 
Africa although its interest remains largely in crude oil and other natural resources that are imported to China. In return, China provides Africa with technology infrastructure, machinery and electronic equipment (Versi, 2006).

Although Canada has been a major player in the mining industry in Africa, there is a huge opportunity for Canadian firms to tap into the market potential of SSA and increase international activities in SSA. Yet global expansion into SSA would require more than an "Africa strategy" to tap into the market potential and recognize opportunities in the SSA market. With recent developments concerning NAFTA and BREXIT, trade relations between Canada and the US have become shaky and unstable (Moore, 2019). Hence, Canadian companies will need to diversify their business profiles and reorient themselves not to depend solely on the US and Europe for global expansion but expand their footprints into other markets like SSA.

Understanding the SSA market, the potential and challenges it presents makes it an interesting context to study. The next section reviews various theories that explain IB activities.

\subsection{Review of IB Theories}

Discovering and exploiting international opportunities is an important strategy for firms and the senior managers who lead them. This has attracted attention among researchers who have developed theories and frameworks to explain this phenomenon. Scholars have addressed various facets of global expansion, and from these topics, important themes and theories have emerged. Of all the frameworks and theories available, this thesis will focus on three conventional IB theories, namely the Uppsala, or process, model, the eclectic paradigm (OLI model) and institutional theory. The attention-based perspective will also be discussed as a theoretical lens for explaining global expansion in distant markets like SSA. 


\subsubsection{The Eclectic Paradigm (OLI Model)}

The eclectic paradigm, or OLI framework (Dunning, 1980, 1988), focuses on decisions of international production, that is, whether or not a firm should engage in FDI. This model provides a unified way of categorizing the advantages a firm has based on its resources, capabilities and location. Hence, this model comprises various theories and perspectives (Kogut \& Zander, 1993; Madhok, 1997; Zaheer, 1995).

According to this model, internationalization activities undertaken by a multinational enterprise (MNE) are determined by the interaction of three variables. First, ownership-specific (O) advantages, meaning that firms with higher competitive advantages inherent in the host country are more likely to increase their foreign presence. Various ownership specific competitive advantages of a firm have been identified in the literature, such as monopolistic power and access to scarce, unique resources and capabilities (Brouthers et al., 1996). Second, locational attraction (L). This refers to the country or region in which the internationalization activity is to take place. The more firms can connect the locational advantages of the host market with their home market competitive advantages, the higher the likelihood of them recognizing opportunities in the host market. The third dimension of the OLI model is internalization (I), which refers to the advantages of using governance structures of foreign production to internalize transactions. The internalization advantages focus on reducing transaction and coordination costs. Internalization is a critical component of the OLI triad as firms decide whether to internalize in their home market or in a foreign market, a choice determined by the costs and benefits of adding value in both markets (Dunning, 2014).

The ownership and location identify the advantages gained from internationalization while internalization identifies the advantages to be gotten from internalizing a transaction. The OLI model is mainly used in decisions to engage in international production (Dunning, 1988, 
2014). Of the three dimensions, the locational advantages of the target country are critical in determining how a firm decides to internalize its activities in the home country as opposed to the target country (Dunning, 1988).

This model clarifies our understanding of the process of global expansion as it reveals that the competitive advantage of a home-country firm is dependent on ownership, locational and internalization advantages in the foreign market. Some firms are able to recognize opportunity in distant markets by properly connecting these advantages in their home market with their host market to expand their activities.

\subsubsection{Uppsala Model}

While the OLI model focuses on global expansion as a function of firm-specific advantages and host-market advantage, the Uppsala model, or process model, explains how internationalization occurs (Johanson \& Vahlne, 1977). It focuses on the gradual acquisition, integration and use of foreign market knowledge to internationalize. This model posits internationalization as a process whereby firms learn by engaging in international activities. Furthermore, internationalization occurs incrementally as firms make an increasing commitment to a selected foreign market. The core component of the Uppsala model is that firms choose the optimal mode for internationalization by weighing the cost and risk based on the market and their firms' resources (Hood \& Young, 1979; Johanson \& Vahlne, 1977).

The Uppsala model has its roots in the work of Penrose (1996), Cyert and March (1963)

and Aharoni (1996). An underlying assumption of the model is that firms experience high uncertainty at the beginning of internationalization because of a lack of market information, but uncertainty is reduced as they learn from their experience in foreign markets. Another underlying assumption is that internationalization begins with foreign markets that are similar to domestic markets in terms of psychic distance (i.e., the perceived difference in institutions of foreign and 
domestic markets), and firms gradually enter markets that are further away in terms of psychic distance. The notion of psychic distance originates in the liability of foreignness, that is, investors face a higher cost of doing business in market overseas than in home market (Jan \& Johanson, 2009; Zaheer, 1995). These costs are directly associated with distance, firm-specific costs due to the unfamiliarity of the host market, costs intrinsic to the host country, which could be economic or legitimacy of business, and costs from the home country (Zaheer, 1995). Therefore, as firms expand globally through incremental commitment to foreign markets, senior managers will increase their commitment to the host market as their knowledge and understanding of foreign markets increases.

\subsubsection{Institutional Theory}

Institutional theory addresses how firms enter and operate in foreign markets in light of their institutional contexts (the rules, norms and values that govern the way business activities are carried out in a market) (Schellenberg et al., 2018; Scott, 2005). Institutional theory posits that firms choose their mode of entry to gain credibility both externally and internally in foreign markets (DiMaggio \& Powell, 1983; Yiu \& Makino, 2002).

The underlying concept in this theory is isomorphism (DiMaggio \& Powell, 1983), which refers to forcing a similarity between two organizations that face the same set of environmental conditions. According to this theory, the organizational structure of a firm is a consequence of organizational response to isomorphic pressures from a firm's internal and external environment (DiMaggio \& Powell 1983; Meyer \& Rowan, 1977; Scott, 1995). Institutional isomorphic change occurs because of three mechanisms: 1) Coercive isomorphism, which refers to formal and informal pressure on organizations by other organizations that are dependent on cultural expectations in the market in which the organization functions. This pressure takes the form of an invitation to collude or a government mandate. 2) Mimetic isomorphism results from a 
response to uncertainty either when organizational technologies are misunderstood or when the environment creates uncertainty, forcing organizations to mimic other organizations. 3) Normative isomorphism takes place in response to pressures brought on by professions. It refers to the collective effort of members in a profession to define the conditions and methods of their work to legitimize occupational autonomy (DiMaggio \& Powell, 1983).

As aforementioned, isomorphic pressure plays a significant role in the entry of a firm into a foreign market, and if institutional theory is correct, then a firm will imitate actions of local partners to legitimatize its operations in a foreign market (Yiu \& Makino, 2002). The institutional environment is characterized by three pillars: regulative, normative and cognitive pillars. The regulative pillar comprises the rules and regulations that bring stability to societies, the normative pillar comprises a society's values, cultures and norms and the cognitive pillar is the cognitive structures that exist in a society (Scott, 1995; Yiu \& Makino, 2002).

The institutional context of a foreign market largely impacts global expansion because of the link between firm capabilities and mode choice (Eriksson et al., 2015). Furthermore, the institutional structure of a foreign market can present legal, political and cultural barriers to the firm's entry. Hence, firms can face a lack of legitimacy and potential extinction (Schwens et al., 2011).

\subsection{Review of Recent IB Theories}

The OLI, Uppsala and institutional theories have all been used to explain internationalization. OLI theory focuses on economic rationales and helps us understand the firm and location advantages that drive internationalization. The Uppsala model helps us understand how firms gradually move beyond their home market. Finally, the institutional theory focuses on the institutional context of the host market that impacts how companies internationalize. However, 
these theories mostly look at the firm as the unit of analysis while the role of the decision-maker remains largely ignored. Explanations of the patterns of global expansion into foreign markets have been put forward recently, such as the business network perspective (Johanson \& Vahlne, 2003, 2015) and managerial cognition (Maitland \& Sammartino, 2015). Next I will discuss the recent IB theories and how they differ from previous theories.

\subsubsection{A Business Network View}

After developing the original internationalization model, Johanson and Vahlne (1977, 2003) revisited it to include a network component. They put forward two arguments: First, markets are a sum of networks of relationships that are linked with one another, and therefore, having insider information of relevant networks is necessary for successful internationalization. If they don't have the requisite information, firms run the risk of liability of outsidership, which is a lack of business market knowledge in a particular business environment. The business network view holds that internationalization knowledge reflects a firm's capabilities for global expansion (Eriksson et al., 1997; Jan \& Johanson, 2009). Second, networks provide opportunities for learning, building trust and fostering commitment, which are fundamental to global expansion and strongly relate to opportunity recognition and identification (Johanson \& Vahlne, 2006, 2009).

The role of networks in the internationalization of firms is one that has been studied by Coviello and Munro (1995, 1997). Their work shows that insidership in networks develops before market entry and has an impact on foreign market selection and the mode of entry. Based on this, Johanson and Vahlne (2003) reworked their original model to further capture the nuances of network influence on internationalization, that is, as a firm creates new knowledge through the exchange of information within its networks, the firm acquires a strong knowledge base for its internationalization decisions. This model also captures how networks are created 
and structured in the host market. It further postulates that the firm is an enabling, yet constraining, business network that includes actors in interdependent relationships (Johanson \& Vahlne, 2003). Hence, building networks for global expansion is an output of the firm's ability to strengthen networks to acquire knowledge of resources, needs and capabilities (Herstad et al., 2014; Hohenthal et al., 2015; Johanson \& Vahlne, 2009).

Additionally, while some knowledge might be unattainable, it is generally embedded with key information, hence the focus becomes less about overcoming institutional barriers, as the process model posits, and more about discovering and creating opportunities for global expansion into foreign market. We see a gradual development of the theories and perspective of the internationalization process from understanding how firms move outside of the home market, to the institutional context surrounding foreign markets, to providing clarity on global expansion in a market. However, these models do not address how senior managers recognize opportunities for global expansion, especially in a distant market like SSA.

\subsubsection{Managerial Cognition}

Senior managers are tasked with the decision of choosing the best international strategy. This decision is a complicated one, usually filled with uncertainty and ambiguity because of the complexities of the foreign market and the limited attention of senior managers. However, we know little about how managers make decisions about global expansion while making sense of the foreign market environment (Maitland \& Sammartino, 2015).

Previous IB models have been unable to clearly detail the role of the senior manager in opportunity recognition in foreign markets (Brouthers \& Hennart, 2007; Reeb et al., 2012). The managerial cognition perspective attempts to explain how senior managers think through and make internationalization decisions. This focus on cognition helps to clarify the cognitive processes involved in firm-level internationalization. 
This perspective is based on the assumption that an individual's ability to process, store and retrieve information is limited. This is known as bounded rationality in decision-making (Brouthers \& Hennart, 2007; Buckley \& Casson, 2009). Therefore, understanding how managers make decisions despite their limited cognitive ability is crucial in clarifying how senior managers engage knowledge domains and information cues in order to make informed decisions when looking for opportunities for global expansion.

Senior managers' mental models and sense-making processes impact their internationalization decisions as they look for opportunities outside their home markets. This is because mental models function as a combination of knowledge and a filter for new information (Aharoni et al., 2011; Maitland \& Sammartino, 2015). A decision-maker's ability to differentiate among different elements of information forms the context in which decision making is carried out. Also, senior managers' ability to not only differentiate the various elements of information but also draw connections among and within knowledge domains is critical to recognizing opportunities for global expansion.

The international experience of senior managers also plays a critical role in their sensemaking abilities. Senior managers who have more international experience in foreign markets will be more connected than those with less experience (Hohenthal et al., 2015; Maitlis \& Christianson, 2014) as they possess critical knowledge of the market, such as government systems, cultural norms, etc. However, a single international experience might not influence a senior manager's internationalization decisions much, hence having a robust and diverse experience in international locations increases the depth of mental models used for making decisions about internationalization (Guler \& Guillén, 2010).

The managerial cognition perspective facilitates a rich understanding of global expansion by drawing on the cognition and sense-making processes of managers. It helps us address the 
challenges of discovering opportunities in distant markets especially since upper-level managers control the decision-making processes that affect global expansion. Hence, how managers think and operate have implications for organizations. The attention-based perspective clarifies this further by emphasizing that how managers use their most limited resource, that is, their attention capacity, will impact what attracts their attention and how they allocate firm resources and firmwide attention. This perspective will be discussed further in the following section.

\subsection{Theoretical Framework: An Attention-Based View of Internationalization in Distant Markets}

Integrating an attention-based perspective adds an important dimension to understanding how senior managers recognize opportunities in distant markets like SSA by providing a clear and more useful way of understanding the rules, players and resources that create situations in which some opportunities, threats, and solutions are more important than others. It further improves our understanding of how the attention capacity of senior managers is directed to relevant issues.

Although IB theories explain the internationalization of firms, they are premised on the assumption that senior managers have the ability to access and attend to information about distant markets. While the value of IB theories is irrefutable, the literature does not clarify how senior managers recognize opportunities, especially those in distant markets.

In contrast, the attention-based perspective is grounded on the theory that a firm's behaviour is the result of how the firm channels and distributes the attention of its decision makers (Ocasio, 1997). Its central argument is that to explain firm behaviour is to explain how firms regulate the attention of their decision makers. "Attention encompasses the noticing, encoding, interpreting, and focusing of time and effort by organization decision-makers on both issues and answers" (Ocasio, 1997). Issues are the "available repertoire of categories for making 
sense of the environment problems, opportunities, and threats" and answers are the available alternative" (Ocasio, 1997, p. 189).

Based on this perspective, I argue that a lack of attentiveness on the part of senior management of Canadian firms to developments, issues, opportunities and threats in the SSA market reveals a pattern of decision making about global expansion that overlooks attractive opportunities in the SSA market. Additionally, because of their limited cognitive capacities, time and financial resources, senior managers are selective in what issues and answers they attend to. Hence, they do not conduct an exhaustive search for opportunities in distant market, which could also explain their oversight of the SSA market as an opportunity (Burt, 1992; Ocasio, 1997). Drawing on this perspective, I suggest the following: First, that senior managers must be aware of the range of information about and cues from the distant market. This involves attention allocation to information from networks sources. Relying on information from networks available to them will, in turn, influence how they determine which market opportunities are worth considering. Second, that information from network sources must be salient (vividness of an information cue or source in the environment ) and come from a credible source to merit the attention of the decision maker Third, that decision makers must also attend to the pre-existing mental models they hold about the distant market. Senior managers typically resort to a heuristic shortcut when faced with an overabundance of information to determine what they attend to (Aharoni, 1966). Therefore, senior managers must filter these shortcuts to decide which opportunities are worth exploring and which ones should be disregarded. 


\section{CHAPTER 3 RESEARCH DESIGN AND METHODOLOGY}

\subsection{Research Approach}

Given my objective to fill the gaps in IB theories and advance theoretical explanations, I chose a multiple-case study as my research design. A multiple-case study relies on relationships that are present in most or all of the cases being studied, resulting in conceptual frameworks or hypotheses that are more parsimonious and generalizable compared to single-case studies (Eisenhardt \& Graebner, 2007; Yin, 2003, 2014).

With the purpose of this study being to clarify how senior managers recognize opportunity in psychic and institutional distant markets, a literal replication strategy (Yin, 2014) was followed. I choose this design because 1) the phenomenon needs to be expanded upon beyond its treatment in the theory (Ridder, 2017), 2) there are nuanced differences in the field of international business (Pothukuchi et al., 2002) and 3) qualitative study in this field is used to answer "how" and "why" questions (Yin, 2014). Specifically, the case study method is an appropriate method to answer the research questions of this thesis as it allows for the use of various data collection methods to provide an in-depth view of the process of how senior managers recognize opportunities worth exploring in SSA.

In this thesis, I use in-depth interviews with senior managers of Canadian firms involved in the internationalization decisions of the organization. The case study approach enabled me to explore specific phenomena such as attention structures and networks as opposed to typical empirical work in IB research (Birkinshaw et al., 2011; Maitland \& Sammartino 2018). In IB research, data has been collected through direct observation and parallel participant interviews (Maitland \& Sammartino, 2018). However, due to the lengthy process and challenges 
encountered in obtaining access to firms, the case study approach was efficient and provided data richness for me.

Cases were selected through purposeful sampling (Siggelkow, 2007; Timmermans \& Tavory, 2012; Yin, 2014). This sampling strategy is used to investigate a new phenomenon that fill gaps in an existing theory from the research question proposed. It was appropriate because it allowed me to begin with an existing theory (i.e., attention-based perspective) and then extend it through case studies. Data triangulation was achieved through the use of multiple sources of data, which provided multiple measures of the phenomenon (Ridder, 2017). An important design of my research was firm selection. Canadian companies who had a presence in SSA or intended to internationalize into Africa were selected.

\subsubsection{Research Timeline}

Starting in September 2019, I conducted preliminary discussions with various senior management members in Canadian companies, trade commissioner officers to SSA and business leaders to understand the process of firm expansion. In early October, I submitted my protocol application to the Research Ethics Board (REB) at Ryerson University. I was still conducting preliminary discussions during this time. At the end of October, my REB protocol application was approved, and formal invitations to participate in interviews were sent to senior managers.

In the first part of the data collection, a simple survey was sent to senior managers. The questions were geared to provide a basic self-assessment of how senior managers attended to information about opportunities and how they acquired information from their networks especially for decisions about internationalization in SSA. The questionnaire also allowed me to gauge how senior managers paid attention to information related to SSA based on the four interrelated cognitive processes: "noticing, encoding, interpreting and focusing on time and effort" (Ocasio 1997, p. 184). 
Noticing is the process by which an individual becomes aware of particular information through a network or contact (Fiske \& Taylor, 2013; Rhee \& Leonardi, 2018). The information must be noticed first before another process can occur. Encoding occurs when the information noticed has been internalized through cognitive and mental processes that update the individual's prior knowledge (Fiske \& Taylor, 2013; Rhee \& Leonardi, 2018). Interpreting is a process of transforming the information and making sense of it (Weick, 1979). Focusing of time and effort involves allocating time and resources to gain more details from the information (Ocasio, 1997). Based on these four processes, I developed open-ended questions that probed the degree to which the respondents engaged in these processes when internationalizing into the SSA market and developing their networks.

After participants had completed the questionnaire, I interviewed them (see interview guide in Appendix A). Respondents were asked about their background and various questions on their companies' internationalization into SSA and their current operations in the market. At the end of the interview, respondents were asked about the value and quality of their firm's business opportunity in SSA in terms of profitability and non-profitability terms.

\subsubsection{Case Selection}

As suggested by Yin (2014), I selected literal replication cases to allow me to predict similar results. The sample was collected based on the following features:

1. Companies must be multinational companies as defined by Kogut and Zander (2003): business organizations whose activities are located in more than two countries and whose economic activities span international borders. This was important because to effectively study the attention patterns of senior managers when it comes to recognizing opportunities in distant markets, the company needs to be involved or seeking economic activities outside Canada. 
2. Companies must be Canadian as well as being incorporated in Canada. This allowed for easy access to companies, but it also allowed me to showcase the interesting dynamic between western, that is, Canadian, firms and distant markets like SSA.

3. Companies must have internationalized or intend to internationalize in SSA. If the company had not internationalized at all or shown no interest in SSA, data collected from the interview would run the risk of being unreliable and irrelevant to the study.

\subsection{Data Collection}

Data collection involved conducting interviews using the procedure outlined by Yin (2014). I conducted a combination of in-depth, semi-structured interviews and a questionnaire to gain a thorough and deep comprehension of opportunity recognition in SSA by Canadian companies that operate in SSA or intend to enter the SSA market. The participants included senior managers, CEOs, chief strategy officers, founders and anyone who could provide information on the internationalization of the company. These participants were recruited through the CanadaAfrica Chamber of Commerce. Participants were chosen because they had been tasked with making important decisions for the company that directly related to global expansion.

The topics covered in the interviews were determined based on previous scholarly theoretical work done on attention pathways, its patterns and allocation within an organization (Rhee \& Leonardi, 2018). Data collection was structured around several components: attention structures, background of the firm and open-ended questions on global expansion. The background questions solicited general business information (size, revenue and employment growth of the firm) and information about senior management, including the number of managers, their tenure, educational background and past experience (work, study or 
internationalization), their functional roles within the team, and the contacts they reached out to when seeking to internationalize in SSA.

This interview guide was written using questions that started with "who, what and how" (Pettigrew et al., 2001, p. 700) to guide the participants' answers. I started by asking background questions to obtain information on the company. This process was important because it allowed me to gain enough inside information on the company to ask meaningful, probing questions. The interview followed this process to allow the participant to give information regarding their attention and networks without any imposition from me. The open-ended questions allowed participants to provide deeper responses in their own words, shedding light on various processes and events (see Table 1 for example questions).

\section{Table 1. Sample Interview Questions}

1. Given your company's (intended) business operations in SSA, think back to the time before you considered SSA. Walk me through the process of when you became aware/first thought of SSA as a potential place to do business.

2. Could you describe a time when you received information about an opportunity in the SSA market that sparked your interest in the region?

3. Could you think back to the people with whom you have discussed/reached out to for business opportunities in SSA?

4. Does anyone on your senior management team have international experience in Africa (work/study experience)?

5. Are there specific functional roles within the senior management team? If so, please list them.

6. Please list the names of people within the company with whom you discuss business opportunities related to SSA.

7. Please make a list of sources/contacts you reach out to when you want to learn about new developments in SSA.

8. How long is a senior management team member's tenure?

9. What is the educational background of team members (business, STEM, law, etc.)?

As data collection progressed, I refined the questions as needed and further developed the interview guide (Eisenhardt, 1989). Also, I avoided leading the participants through the process by being attentive and asking follow-up questions to probe deeper and gain more insight (Gioia 
et al., 2013, p. 19). The questionnaire took about 10 mins to complete while the interview lasted 30 to 50 minutes. The interviews were audio-recorded and transcribed verbatim. To further understand the case companies, I gathered data from their websites and sent emails to interviewees after the interview if I needed additional information and clarification.

\subsection{Interview Process}

Prior to the interview, a recruiting script and consent letter was sent to the participants to briefly explain the research topic and inform them of their rights as participants. A consent form for permission to record the interview was also sent, which was signed and sent back via email before the interview began. Afterwards, I reached out to clarify any misconceptions to ensure the reliability of the data.

Table 2. Overview of Data Collection

\begin{tabular}{|c|c|c|c|}
\hline Company & Type & Length & Participant \\
\hline A & Preliminary \& phone interview & 50 mins & Founder \\
\hline B & Phone \& email follow up & 40 mins & Founder \\
\hline C & Phone \& email follow up & 30 mins & President \\
\hline D & Preliminary \& phone & 35 mins & Founder \& CEO \\
\hline E & Phone \& email follow-up & 40 mins & CSO \& co-founder \\
\hline F & Preliminary \& Skype & 50 mins & Founder \\
\hline G & Phone \& email follow up & 30 mins & Co-founder \\
\hline
\end{tabular}

\subsection{Data Analysis}

Following the interviews, the audio recording was transcribed verbatim and all information that could be used to identify the interviewees were removed from the transcriptions. After transcribing the interview, I read the transcription from beginning to end to better understand the 
data. After this preliminary reading, the data strongly indicated that social networks played a crucial role in the decision-makers' allocation of their attention to foreign markets. It also became apparent that senior managers engaged in a "pre-noticing" phase when seeking opportunities for global expansion in distant markets.

The next step was a detailed examination of the data. The data was analyzed using pattern-matching logic (Yin, 2014) to compare empirically based patterns with predicted patterns, This enabled data analysis leading to a clarification or extension of the theory. Due to the nature of the data (i.e., data from multiple but comparable case companies), I also used open, line-by-line coding (Price, 2010). This included within- and cross-case comparison, coding and labeling of the data. Open coding allowed me to analyze and categorize raw data. Line-by-line coding was beneficial in that it limited the possibility of omitting an important category in the coding. For example, in the extract below I would have coded the sample text as "networks" if it had not been coded line by line. As shown in Table 3, there are three different codes explaining different aspects of networks.

\section{Extract-Interview 2 (Company B)}

Question: How did you go about gaining information on SSA?

Answer: I would say most of the knowledge that we gained was through our own networking. I mean, it took us probably a couple of years and most of the information quite frankly, was through diaspora here in Canada.

\section{Table 3. Example of Line-by-Line Coding of Data}

\begin{tabular}{|l|l|}
\hline \multicolumn{1}{|c|}{ Sample Text } & \multicolumn{1}{|c|}{ Code } \\
\hline $\begin{array}{l}\text { I would say most of the knowledge that we } \\
\text { gained was through our own networking. }\end{array}$ & Knowledge is gained through networking \\
$\begin{array}{l}\text { I mean, it took us probably a couple of years and } \\
\text { most of the information quite, frankly, was } \\
\text { through diaspora here in Canada. }\end{array}$ & $\begin{array}{l}\text { Gathering networks takes time } \\
\text { Diaspora network is an information } \\
\text { source }\end{array}$ \\
\hline
\end{tabular}


Some of the codes are duplicated or are similar in line-by-line coding, and they can have an extension from the parent code, for example "internationalization" as the parent code of "reason for internationalization." Any terms or phrases that influenced concepts, like "noticing," "encoding," "focusing of time and effort" and "scanning" were coded. Also, any terms or phrases related to business activities in SSA countries were coded. Finally, any phrase or sentence that related to influencing a decision to engage in business activities and recognizing opportunities in SSA countries was coded to ensure that the analysis captured the nuances of senior managers' attention processes.

There were 38 codes in total (see Appendix B for the final codebook). The majority of these codes emerged after the first four interviews. Therefore, this study reached theoretical saturation after four case interviews, which is in line with most case study theories and research (Guest et al., 2006; Romney et al., 1986).

In sum, the data was analyzed with the theoretical frameworks in mind to ensure a succinct and reliable analysis (Yin, 2014). All analysis was text-based, and the interview was transcribed and analyzed with the QSR NVivo package, a computer software designed for qualitative studies that helped me organize, store, analyze and visualize the emerging concepts while discovering insights in the raw data. The QSR NVivo package was helpful in conducting a cross-case analysis to identify similarities, differences and patterns among the case companies (Yin, 2014).

\subsection{Limitation of Methodology}

A major limitation to qualitative case studies is that results and analysis cannot be statistically tested, and the process is highly subjective (Eisenhardt, 1989). To reduce subjectivity, methods and tactics like not leading the participants, open coding and clarifying data analysis results were 
applied. This study is also limited in its scope, having a single investigator, other techniques such as data triangulation and intercoder reliability test would reduce subjectivity. Future studies can address these issues, which would improve the rigor of this study. Other limitations are discussed in the next chapter. 


\section{CHAPTER 4 RESULTS}

Yin (2014) suggests a method of within- and cross-case analysis to analyze case study data. Using a within-case analysis facilitated familiarity with the data and specifically with each case company as an individual case but also allowed me to analyze across the various case companies. In the cross-case analysis, the case companies were analyzed based on 1) the attention process of senior managers in recognizing opportunities in SSA and 2) the socio-cognitive process used by senior managers to transform opportunity into business activities in SSA.

I present the data in summary tables for both theoretical replication and empirical richness (Yin, 2014). Table 4 presents an overview of the case companies on a within-case basis. Tables 5 (section 4.2) concludes my discussion of the cross-case patterns and differences and leads to the discussion of the findings. 


\subsection{Within-Case Analysis}

Table 4. Overview of Case Companies

\begin{tabular}{|c|c|c|c|c|c|c|}
\hline Co. & Business description & $\begin{array}{l}\text { \# of } \\
\text { employees }\end{array}$ & $\begin{array}{l}\text { Founding } \\
\text { year }\end{array}$ & $\begin{array}{l}\text { Perceived } \\
\text { quality of } \\
\text { opportunity }\end{array}$ & $\begin{array}{l}\text { \# of senior } \\
\text { managers } \\
\text { with } \\
\text { previous } \\
\text { experience } \\
\text { in SSA }\end{array}$ & $\begin{array}{l}\text { SSA } \\
\text { countries in } \\
\text { which the co. } \\
\text { operates }\end{array}$ \\
\hline A & $\begin{array}{l}\text { Consulting service } \\
\text { providing export } \\
\text { investment services }\end{array}$ & 3 & 2006 & Medium & 1 & $\begin{array}{l}\text { South Africa, } \\
\text { Namibia, } \\
\text { Tanzania, } \\
\text { Ethiopia }\end{array}$ \\
\hline B & $\begin{array}{l}\text { Consulting service in } \\
\text { the manufacturing, } \\
\text { health care and telecom } \\
\text { industries }\end{array}$ & $1-10$ & 2000 & Medium & 1 & Nigeria \\
\hline $\mathrm{C}$ & $\begin{array}{l}\text { Professional service } \\
\text { providing engineering } \\
\text { and urban planning } \\
\text { services. }\end{array}$ & $20-50$ & 1964 & High & 4 & $\begin{array}{l}\text { Ethiopia, } \\
\text { Uganda, } \\
\text { Rwanda, } \\
\text { Kenya, } \\
\text { Tanzania, } \\
\text { Mozambique, } \\
\text { Botswana, } \\
\text { Zambia }\end{array}$ \\
\hline $\mathrm{D}$ & $\begin{array}{l}\text { Solar and energy } \\
\text { provider }\end{array}$ & $5-11$ & 2006 & High & 1 & $\begin{array}{l}\text { Botswana, } \\
\text { Kenya }\end{array}$ \\
\hline $\mathrm{E}$ & Agri-tech & $1-10$ & 2017 & High & 4 & $\begin{array}{l}\text { Botswana, } \\
\text { Nigeria }\end{array}$ \\
\hline $\mathrm{F}$ & IT consulting & 1 & 2015 & Medium & 1 & $\begin{array}{l}\text { Ghana, } \\
\text { Tanzania, } \\
\text { South Africa, } \\
\text { Rwanda } \\
\end{array}$ \\
\hline G & Solar energy provider & $5-12$ & 1985 & High & 3 & $\begin{array}{l}\text { Ghana, } \\
\text { Mozambique, } \\
\text { Liberia, } \\
\text { Tanzania }\end{array}$ \\
\hline
\end{tabular}

\subsubsection{Company $A$}

Company A is a management consulting firm that provides consulting services for Canadian companies expanding into SSA and Asia. Company A was founded in 2006 and currently has operations in South Africa, Namibia, Tanzania and Ethiopia. The founder has degrees in international relations and business administration, coupled with past experience in export 
investment consulting in the natural resources and mining industries. The CEO is the main decision maker for the company. Opportunity recognition in the SSA market began when past co-workers and team members suggested the company should consider entering the SSA market. The CEO had experience working in the Asia market and realized there were some market opportunities in Asia that could be leveraged in the SSA market. The decision to expand into SSA came about after the firm has been in the Canadian market 5+ years and after the CEO recognized the value of the SSA market through his network. Company A has leveraged networks and the experience of the CEO to seek opportunities for expansion into the SSA market by attending to networks and translating the information on the opportunity from the SSA market into a global expansion decision. In summary, Company A has been able to expand its business activities from Canada and Asia into SSA because of the previous experience of the senior manager and social networks built in the past.

\subsubsection{Company B}

Company B is a consulting firm that provides services in manufacturing, health care, telecom, energy and natural resources for its clients. The company was founded in 2000. Its founder has 37+ years' experience in management consulting and an educational background in business. The company senior management team consists of individuals with highly skilled experience in management consulting who have educational backgrounds in business management. However, the founder makes the global expansion decisions.

An opportunity in the SSA market was brought to the attention of the CEO through a personal connection who had been working in SSA. This personal connection was critical to Company B noticing the SSA market because it was the first internationalization activity for the company. The opportunity was pursued by networking with a large network of diasporic 
Africans in Canada and Africans in SSA. Without the personal connection to someone in the region, the CEO would not have considered the SSA market as a place in which to do business.

As of the interview date, Company $\mathrm{B}$ was in the process of exploring a business opportunity in Nigeria and had established contacts in Kenya for future global expansion into the Kenyan market. The company recently had an opportunity for a strategic planning project in SSA that materialized from information from a critical source. While this current opportunity is a high value opportunity for Company $\mathrm{B}$, the CEO will keep evaluating newer opportunities through networks and sources to ensure only minimal risks are involved. While Company B focuses the majority of its strengths on its Canadian operations, the current opportunity in the SSA market is a positive sign for future market activities in the SSA region. Finally, Company B is a young company that has recently expanded its operation into the SSA market. Because of a personal connection to the continent, the CEO attended to information from a critical source to recognize the opportunity in the SSA market and expand the company's operations.

\subsubsection{Company $C$}

Company $\mathrm{C}$ provides professional services in the civil engineering and urban planning industries. In particular, it provides consulting and advisory services on global infrastructure projects for companies around the world. Founded in Canada in 1964, Company C has operations in 50 countries and four continents. This company is well-established and has found opportunities in foreign markets. Global expansion into SSA was easy for this company because of its previous experience operating in international markets. However, for the SSA market, opportunity recognition resulted from the organizational structure of the firm. The company is an employeeowned company, and this largely influenced opportunity recognition. Global expansion into SSA came after an employee, who had had previous experience in Kenya, suggested the company expand into that market. Global expansion decisions are suggested by employees regardless of 
their position, but suggestions are critically evaluated before acted upon. Senior managers in Company $\mathrm{C}$ seek global opportunities differently than managers of companies in the early stages in their internationalization process. Apart from the influence of employees in recognizing opportunities, well-established companies like Company $\mathrm{C}$ reach out to multi-lateral agencies for global opportunities and use their resources to gain market information for global expansion.

\subsubsection{Company $D$}

The interview with the founder of Company D was conducted in February 2020 after he returned from a trade mission trip to Botswana in the fall of 2019. Thus, the following description was based on Company D's current situation before the trade mission and after the trade mission. Company D is a solar and energy company that provides turnkey energy solutions for businesses and residential customers. The company also provides energy audits and electric vehicle charging stations. It services clients primarily in Canada and Sri Lanka. With the CEO having an educational background in engineering, the case company was founded in 2006. The founder is the main decision maker for global expansion activities.

In terms of opportunity recognition, global expansion into the SSA market was driven by the need to solve energy problems in developing places like Sri Lanka and Africa. As a result, this initial motivation drew the founder's attention to SSA to seek opportunities that matched the core value of the company. Global expansion into SSA originally started with a solar project in Tanzania in 2009, which did not materialize because of market challenges. However, after building more networks and gaining more experience, the founder was able to begin another project in Botswana, which is valuable because of a high market need. The founder is in the process of expanding the opportunity to capture value in the SSA market. 


\subsubsection{Company $E$}

Company $\mathrm{E}$ is an agri-tech company that supports farming communities and seeks to address food security issues. It delivers year-round sustainable farming solutions to optimize crop production with the use of hydroponics and data analytics. Founded by an agricultural officer from Sri Lanka, the company improves farming communities and farming practices in droughtprone and developing countries. The company was founded in 2017 , and despite being a young start-up company, it demonstrates a strong international scope and taste for rapid internationalization shown by its internationalization into the Nigerian market and most recently Botswana. Headquartered in Canada, Company E has four senior management members who have strong backgrounds and experience in design engineering, robotics, 3D sensors and data analytics. These experiences contribute to the overall internationalization capacity of the company.

The company currently runs a project in Nigeria, and at the time of the interview had recently expanded into Botswana. Company E also have a strong team of advisors from SSA who advise the senior managers on business activities in SSA, which is important in helping them recognize opportunities for global expansion in distant markets.

\subsubsection{Company $F$}

Company F is an IT solutions company that was founded in 2015. This company is in a preliminary stage of seeking global opportunities in the SSA market. The CEO has an educational background in information technology and currently runs company operations in Canada. At the time of interview, the CEO was seeking expansion opportunities in Ghana, Tanzania and South Africa. Seeing that no opportunity has actualized yet, the interview focused mainly on exploring current processes of discovering opportunities in the SSA market, initial reasons for expanding and categorizations of the SSA market. In opportunity recognition terms, 
the founder had focused on building networks, gaining referrals and sourcing information for opportunities in the SSA market.

\subsubsection{Company $G$}

Company G is a solar energy company founded in 1985 that started as a security systems provider before entering the solar energy field. The co-founder introduced solar power as a new solution to help solve existing customer problems. Senior managers have backgrounds in solar energy and technical engineering that helped to introduce solar energy as a company service. The company is a leader in solar energy in the Canadian and American markets with projects in Ghana, Liberia, Tanzania, Botswana and the Caribbean to provide solar power generation installation. The company models equity ownership and carries out projects with public and private investors. The company has also been able to build strong partnerships and relations with government and make personal connections in the markets they operate in.

In terms of opportunity recognition in the SSA market, Company G had its first entry into the Ghanaian and Tanzanian markets through its SSA diaspora network that kick-started its market activities in SSA. At the time of the interview, Company G had expanded into the SSA market by leveraging personal networks and partnerships with contacts in SSA.

\subsection{Across-Case Analysis}

Based on the interview data collected, I present my analysis by describing the opportunity recognition processes of the senior management of the case companies based on the following themes: pre-noticing phase, salience or accessibility of social information cues, sources, and the salience or accessibility of impersonal information cues.

The attention perspective is socio-cognitive in nature, hence, how decision-makers attend to information gleaned from networks and how they understand the need for such contacts to 
recognize market opportunities will form the foundation for this analysis. As mentioned earlier, the attention of decision-makers is limited, affecting how they attend to information.

\subsubsection{Pre-Noticing Phase (Initial Expectations, Categorization and Motivation)}

Senior managers' ability to recognize opportunities depends on their initial expectations and categorization of the SSA market and their reasons for entering it. This pre-noticing phase is a sum of the mental processes and preconceived notions that senior managers engage in before they begin to notice opportunities in a distant market like SSA. All the interviewees engaged in the pre-noticing phase, which, in turn, drew their attention to the SSA market. To discover opportunities in the SSA market, CEO of Company A categorized the market as similar to the Asian market by drawing from his experience and making a connection between his firm's global expansion into the Asian market with the SSA market:

I spent most of my working career in Asia. I sort of did you know my due diligence and it looked to me like Africa was poised to become in a way the new Asia. My concern was Canadian companies will come late to Africa in the same way they came late to Asia. I started consulting to keep companies on the market expansion internationally, that's what I've been doing in my company, that's the genesis of my interest in Africa. (Company A, Founder)

We're [Canada]part of the British Commonwealth. There's a lot of commonality in the legal system and the laws, which makes it [market] easier to deal with. So, you can look at some of the laws and regulations and they are very similar to the laws in Canada as well and a government structure in Africa is similar to the structure of Canadian government. So, that makes it a little bit easier. (Company C, President)

The initial expectation of Company $\mathrm{C}$ and Company A that SSA would be like Asia is an example of how senior managers expect the market to function. These expectations affect how they approach the market and attend to information from networks and sources.

Another way senior managers engaged in the pre-noticing phase was through their mental categorization of the markets they chose to enter. Mental categorization of the market is influenced by preconceived notions and popular media representations of SSA. Senior managers 
then bring these categorizations to their encounter with information or search for opportunities in distant markets like SSA. This then impacts how they attend to information from sources and make internationalization decisions. An excerpt from the interview with Company B's CEO reveals how he categorized the SSA market based on information formed from pre-existing mental models and popular media representations:

To be perfectly honest, the only thing I knew about Nigeria before then was Boko Haram and spam emails, and that was it if it had not been for my son going there [Nigeria], it's not something [doing business in West Africa] we would have even considered. (Company B, Founder).

The pre-noticing phase also included senior managers' reasons for global expansion into distant markets. The initial motivation for global expansion influenced how senior managers directed their attention:

We know that various people that we have met with in various places in Africa suffer from very high-power costs, lower reliability or lack of access all together. (Company G, Co-founder)

I know almost all African countries don't have grid-connected electricity, which is similar to Sri Lanka, so that been said, I saw the potential, and I've been trying to expand into the region. (Company D, CEO)

All interviewees identified a process that preceded their expansion into SSA. This process meant attending to the intersection of past experience, reasons for expansion and mental categorization of the distant market before pursuing opportunities further.

\subsubsection{Salience and Accessibility of Networks and Sources of Information}

To recognize opportunities in the SSA market, companies developed networks (A, C, D, E, G) or sought referrals (B, F) to gain information on the market. Company managers recognized opportunities in the SSA markets because of the salience (i.e., external factors such as the prominence or vividness of an information cue or source in the environment) and accessibility (i.e., the internalized knowledge structures such as the ease with which they could recall or 
activate certain pre-existing beliefs) of the network sources they had. The following quotations

reveal how the salience and accessibility of networks impacted opportunity recognition in the

SSA market among senior managers.

We worked with partners in Africa and built a team of advisors, a couple of them are all from the region. So, you know they introduced to us, to the continent and opportunities in the market. (Company E, CSO)

There was one person that was originally from Kenya who was in [the] private banking industry. He had spent quite a number of years in Canada and was well versed about all the opportunities in Nigeria and Kenya. We went through opportunities in the industry sector by sector, and he described the players and other critical information. You know, stay away from that industry sector because it's very corrupt, and this one is dominated by this, and so it's conversations like that that makes us aware of market opportunities, and again, we didn't go in cold. (Company B, Founder)

It's been existing relationships that we have here in Ontario, that have led to our activities in Kenya and in Mozambique. (Company G, Co-founder)

So, I had a couple of team members in the company who were in Africa before. You know, from them we got information on Africa, they know the stability, political situations there. So, they have been able to, you know, help us narrow down parts that we wouldn't have information on. (Company D, Founder).

It was mostly senior people in the department, upper management and members of [the] upper management team" there were some members of [the] upper management team looking at Africa and thinking I had done a good job in helping stir the Canadian companies to emerging markets like Thailand, Cambodia, Laos and in many places and you know a lot of the problem that we see in some of those emerging Asian market are similar to what we see in African markets. (Company A, Founder)

In a case where the necessary information is not available, referrals become a critical source of information. Referrals are also important when the knowledge bank of a particular contact has been exhausted and senior managers need more information to realize an opportunity.

So, we started off with people that we knew here in Canada, and asked who they knew in Africa, and through those referrals, we ended up connecting with people in Nigeria, and some of whom were consultants as well. We were initially thinking of going direct and developing business ourselves, but it became obvious that who you know is critically important. (Company B, Founder) 


\subsubsection{Sense making}

Attending to information from networks and sources is not sufficient to recognize market opportunities. Such information must be encoded with positive mental schemas and models to properly attach meaning to in a way that highlights the opportunities in the SSA market.

You know one person thought it was dangerous to go after some opportunities and other people thought it was not a big deal. So, we would kind of talk more with those people we thought might have a better understanding. (Company B, Founder)

In a situation where an opportunity has been recognized but seems risky or conflicting, senior managers have to make sense of the information to capture the value of the opportunity and sort out any conflicting information, as revealed in Company B.

So, we initially had a question about an opportunity, and we needed to find out if it was concrete. Somebody contacted us from Kenya, he was so serious about the opportunity and wanted to bring us on board with the project but when we put it through to the trade commissioner, we found out that the information wasn't as true as they made it seem. (Company D, CEO)

In the excerpt above, company staff identified an opportunity, but the senior manager still had to process the opportunity to ensure its value. By going through the trade commissioner, the senior manager was able to make sense of the information and determine whether it was worth exploring or not.

In a couple of minor instances if we come across conflicting information, not that we thought the information was wrong, we would still validate it with someone else and confirm if they had similar experience as well. (Company B, Founder)

When expanding into distant markets like SSA, senior managers encounter conflicting information, hence, their ability to make sense of the information and clarify any risk and identify loopholes strengthens the market opportunity.

I know I am in IT and everything runs in the West but when comes [to] Africa it comes down to if there [is] infrastructure to support the business, and if there is none, a better way to expand to Africa might be to start with some infrastructure type of venture. (Company F, Founder) 
When information from a source or network is unclear or conflicting, senior managers' ability to process the information in a way that realizes opportunity is important. The reliability and quality of the source from which the information comes is also important in determining how the information will be attended to. Also, the time and effort taken to ensure the information is clear and not contradictory reveals the attending effort of the decision-maker.

If something is not clear to us, we interact with the people presenting the opportunity until we get [a] clear understanding to make a decision. If at any point it becomes clear and it's in our interest or not, we then decide on what to do. So, it's not only about finding the opportunity, we evaluate it carefully before taking it at face value. (Company $\mathrm{D}, \mathrm{CEO})$

Our advisors are from the continent. I think that it is very important to have our advisors because they bring [a] local perspective to ensure that we are navigating both, like, both the cultural and the government processes of the market properly. (Company E, CSO)

In our Nairobi market we got some confusing information which can be challenging and that's clearly where our partners on [the] ground in Africa helps us navigate understanding the complexities. (Company G, Co-founder)

In the sense-making process, senior managers make sense of opportunities by fact-checking them with their networks. This process ensures that senior managers gain clarity on the market opportunity before making a global expansion decision. As shown in the case examples above, when senior managers encounter information about opportunities that is unfamiliar or contradictory, credible networks facilitate the sense-making process which impacts how senior managers pay attention to their sources.

\subsubsection{Perceived Value and Quality of Opportunity Recognition}

Opportunity recognition is the goal of every global expansion activity. However, before expanding into a distant market, senior managers must perceive the expansion's quality and value for the firm positively should the opportunity materialize. Here is an example of how senior managers perceived the quality of an opportunity realized in the SSA market they operate in: 
So, he [CEO]was patient in allowing us [management team] [to] explore opportunities in Africa. Although he was concerned that we would spend lots of money, time and effort, and maybe it would just be a white elephant in the end, I'm sure it took a lot of time and an effort, but we were able to make it successful. (Company G, co-founder)

The CEO of Company G was skeptical about expanding into the SSA market but with direction from one of the co-founders, the company was able to enter the SSA and be successful.

From my company's point of view, we see Africa and more countries that we're in currently as being the number one opportunity in the world for expansion in terms of revenue and maintaining a similar level of profitability. The reason being that the African economies are growing quite fast and they need infrastructure. And we're in the business of designing and supervising the construction of infrastructure. So, we see a big demand coming out of Africa. (Company C, President)

Matching firm specific advantages with a country's need helps senior managers recognize opportunities to expand into the market.

It's a high possibility not only in Botswana but in every other place. A lot of other places are improving and getting better and we are also establishing more context in other places. So, you know, profitability will happen, I strongly believe it will happen. (Company D, CEO)

Ethiopia was the first and probably our favorite place to do business in Africa at the moment. But then we saw the list and we have since expanded from that. What you find is that the governments talk to each other. So, you know, Ethiopia talks to Uganda, talks then to Rwanda and to Tanzania, and they recommend you [business]. That's how we gradually expanded down the east side of Africa. (Company C, President)

In the case of Company $\mathrm{C}$, the ease of expanding into other countries once a first entry was made was an added opportunity for the firm. Also, the strength of referrals from governments reflects positively on the firm operating in the market.

Opportunities took various forms for the case companies. Across the companies, opportunity was categorized in monetary measures like profitability, growth and expansion but was also conceptualized in non-monetary measures such as value added to SSA, solving a problem to fill a need and social responsibility:

And then just on the sort of the social impact side you know, the opportunity to support an ecosystem where we're minimizing the use of water, land and preserving our natural 
resources, and being able to support the production of a locally fresh produce means that you can bring down the prices of certain products. It also increases the availability of nutritious products. (Company E, CSO)

And so, we see our value to the folks there in Africa as certainly much more than just a hardware vendor and we've heard from them. What we want to do is a venture more of a local community where we can convey knowledge and experience and build together, that's more the approach. (Company G, Co-founder)

In conclusion, the perceived or actualized opportunity in the SSA market recognized by senior managers is an expression of shifting their attention to information from various sources. It is also an expression of how they encode information in a way that overrides pre-existing biases to recognize opportunities in SSA.

\subsubsection{Summarizing the Patterns and Differences}

In Chapter 4 I discuss the case companies, highlighting patterns and differences through a crosscase analysis. This analysis is done to capture novel findings across the case companies based on four distinct attention processes used by the case companies. Table 5 summarizes the patterns and difference among the case companies and shows how senior managers attended to opportunities in the SSA market. The summary leads to the discussion in the Chapter 5 and answers the questions raised in this study. 
Table 5. Patterns and Differences among Case Companies

\begin{tabular}{|c|c|}
\hline Patterns & Differences \\
\hline \multicolumn{2}{|c|}{ Pre-noticing phase } \\
\hline $\begin{array}{l}\text { - Case companies paying attention to } \\
\text { opportunities was a combination of intial } \\
\text { motivation and categorization of the market } \\
\text { by senior managers. } \\
\text { - Senior managers attended to opportunities } \\
\text { because of previous experience in SSA } \\
\text { through a close network source. } \\
\text { - Opportunity recognition was motivated by } \\
\text { altruism to solve a need in the distant } \\
\text { market. }\end{array}$ & $\begin{array}{l}\text { - Case companies had different reasons for } \\
\text { expanding into the SSA market. }\end{array}$ \\
\hline \multicolumn{2}{|c|}{ Salience and accessibility of networks and sources of information } \\
\hline $\begin{array}{l}\text { - Networks were developed from personal } \\
\text { contacts and an inner circle of influence } \\
\text { before seeking information from external } \\
\text { sources. } \\
\text { - Companies generally sourced information } \\
\text { from networks, and the credibility of such } \\
\text { information was validated by trustworthy } \\
\text { external networks. } \\
\text { - It was valuable to have senior management } \\
\text { who had previous experience in Africa. }\end{array}$ & $\begin{array}{l}\text { - Gaining referrals about a situation with } \\
\text { limited information about the specific } \\
\text { market was not common across case } \\
\text { companies. }\end{array}$ \\
\hline \multicolumn{2}{|c|}{ Sense making } \\
\hline $\begin{array}{l}\text { - Companies made sense of contradictory } \\
\text { information from a network by contacting a } \\
\text { trusted source, most likely a government } \\
\text { agent, international agency or a reliable } \\
\text { contact. } \\
\text { Case companies spent significant timein } \\
\text { understanding the information received } \\
\text { before realizing an opportunity that was } \\
\text { profitable from a business stand point. }\end{array}$ & $\begin{array}{l}\text { - Not all case companies had dificulty with } \\
\text { this process because of the ease and } \\
\text { transparency in the market they chose to } \\
\text { internationalize in. }\end{array}$ \\
\hline \multicolumn{2}{|c|}{ Perceived quality and value of opportunity } \\
\hline $\begin{array}{l}\text { - Most companies agreed with the potential } \\
\text { and actualized value of their } \\
\text { internationalization opportunity in SSA } \\
\text { despite the market challenges they faced. } \\
\text { They also saw opportunities for further } \\
\text { expansion into other regions following their } \\
\text { first entry. }\end{array}$ & $\begin{array}{l}\text { - Some companies expressed uncertainty in } \\
\text { the potential value due to the high risk of } \\
\text { doing business. }\end{array}$ \\
\hline
\end{tabular}




\section{CHAPTER 5 DISCUSSION}

This thesis investigates two central research questions: 1) How do senior managers' attention patterns enable opportunity recognition in SSA countries? 2) How do senior managers collect useful information from networks and translate it into a business opportunity in SSA countries. Together with Chapter 4, this chapter discusses patterns and differences captured from the cases. This leads to the development of a conceptual model clarifying how senior managers discover opportunities in distant markets.

As mentioned earlier, while there are upsides in the SSA market, there are also challenges, such as political instability and unfavorable market institutions, that make it difficult for senior managers to recognize opportunities. However, if senior managers can translate these risks to opportunities and not remain fixated on the issues, opportunities can be recognized.

I used insights from this study to develop a conceptual framework that represents the opportunity recognition process in Canadian expansion into the SSA market. Before senior managers begin to discover opportunities for expansion into distant markets, they engage in a pre-noticing phase (see Figure 3). This pre-noticing phase is characterized by their initial expectations and categorization of the market and reasons for entering it and is influenced by the salience and accessibility of social information and/or impersonal information. This then affects how senior managers begin to notice information.

As previously discussed, the liability of foreignness suggests that a firm's global expansion depends on the relative ease of identifying opportunities in a foreign market (Zaheer, 1995). Hence, having the right networks reduces this liability. The findings and insights from my attention-based perspective clarify these insights in several ways. They confirm that the 
challenge of identifying opportunities in foreign markets, such as SSA countries, is a major impediment to global expansion of Western companies. Furthermore, they suggest that this challenge primarily plays out at the level of senior managers. Senior managers typically categorize the SSA market based on how they attend to information from their networks. In a case where negative impressions were formed, networks that were seen as less reliable or less credible were ignored. As a result, these senior managers could be missing out on opportunities in the SSA market.

This thesis clarifies this process further by suggesting that the reasons surrounding the desire to expand into the SSA market impacts how senior managers attend to opportunities outside of the Canadian market. Senior managers were motivated either by altruistic desires to solve a need in SSA or to have a social impact in the market they operated in. Therefore, the motivating factors that drive global expansion were influenced by how senior managers attended to information from networks and connected it with their motivations, to find opportunities in the market.

The findings from this thesis also highlight a difference in the type of networks senior managers liaised with in the pre-noticing phase. While the salience and accessibility of information from sources impacted global expansion decisions, senior managers reached out to well-established multilateral agencies such as the African Development Bank and trade commissioner offices and networked through personal connections at different stages of the noticing process.

This further indicates that senior managers take various types of information into account when seeking opportunities in SSA. While social information can be obtained from personal networks, multilateral agencies provide more in-depth impersonal market information. They are also seen as actors that are reputable and can validate information that comes from a market 
region. Personal networks provide information that is peculiar to market like meeting the people that are needed to do business, which is easier and simpler to attend to. Also, small players in the market might not have access to information from multilateral agencies or the resources to make sense of the broad information provided by large agencies.

In the managerial cognition perspective (Maitland \& Sammartino, 2015), senior managers have a limited ability to process and store information and their mental models and sense-making processes impact how they recognize opportunities in foreign markets. The findings and insights from my attention-based study confirm and clarify these insights. They reinforce the finding that the challenges that senior managers face in institutionally distant foreign markets, such as SSA countries, can undermine their ability to recognize opportunities in them. It extends the managerial cognition perspective by suggesting that senior managers' mental categorization of the foreign market can positively or negatively impact their attention to opportunities in a market. For example, if the decision-maker has a preconceived conception that Africa is a corrupt region, then they are unlikely to notice alternative information coming from that region and they would exclude Africa as a location for global expansion. Conversely, if senior managers have positive mental categories of the SSA market, such as "increased ease of doing business" or "relatively young population," they are more likely to recognize opportunities in it.

Additionally, senior managers typically approach the SSA market with mental expectations, either positive or negative, and such expectations, in turn, impact how they attend to information from their networks. For example, a senior manager who has certain expectations about the SSA market will only notice information from networks that fits that expectation. Hence, they are only able to recognize opportunities that meet their expectation of the market. This thesis further suggests that if senior managers are able to adjust their expectations of the 
market, they are more likely to discover opportunities for global expansion in it. If a senior manager has positive expectations (given similarities with previous experience or alignment with firm-specific advantages), they are more likely to recognize opportunities in the market. However, a negative expectation of a market could be a hinderance to recognizing opportunities in institutionally distant markets, such SSA countries. Hence, related information from various sources would go unnoticed.

The insights from this thesis show that senior managers categorize distant market to discover opportunities, which impacts the networks they seek and how much prominence they give to information from networks. Therefore, their mental models and schemas dictate what falls into their purview. Consequently, they attach specific meanings and quality to sources before they begin to search for opportunities. Hence, senior managers only notice information that is consistent with their schemas and mental models. For example, if senior managers who are looking to enter a specific SSA market have "credibility" as a high schema, they would most likely notice information that they perceive as credible, regardless of where the information is coming from, and disregard any source they perceive as less credible.

As previously discussed, the attention-based perspective suggests that the attention of decision makers is related to firm strategy. It further suggests that attention processes include how senior managers notice and encode issues and answers (i.e., information is first noticed, then encoded and so on; Ocasio, 1997). This thesis further clarifies and extends this perspective by suggesting a pre-noticing phase; before senior managers begin to notice information from sources, they engage in a pre-noticing phase that acts as a filtering process. 
Figure 3. Conceptual Framework

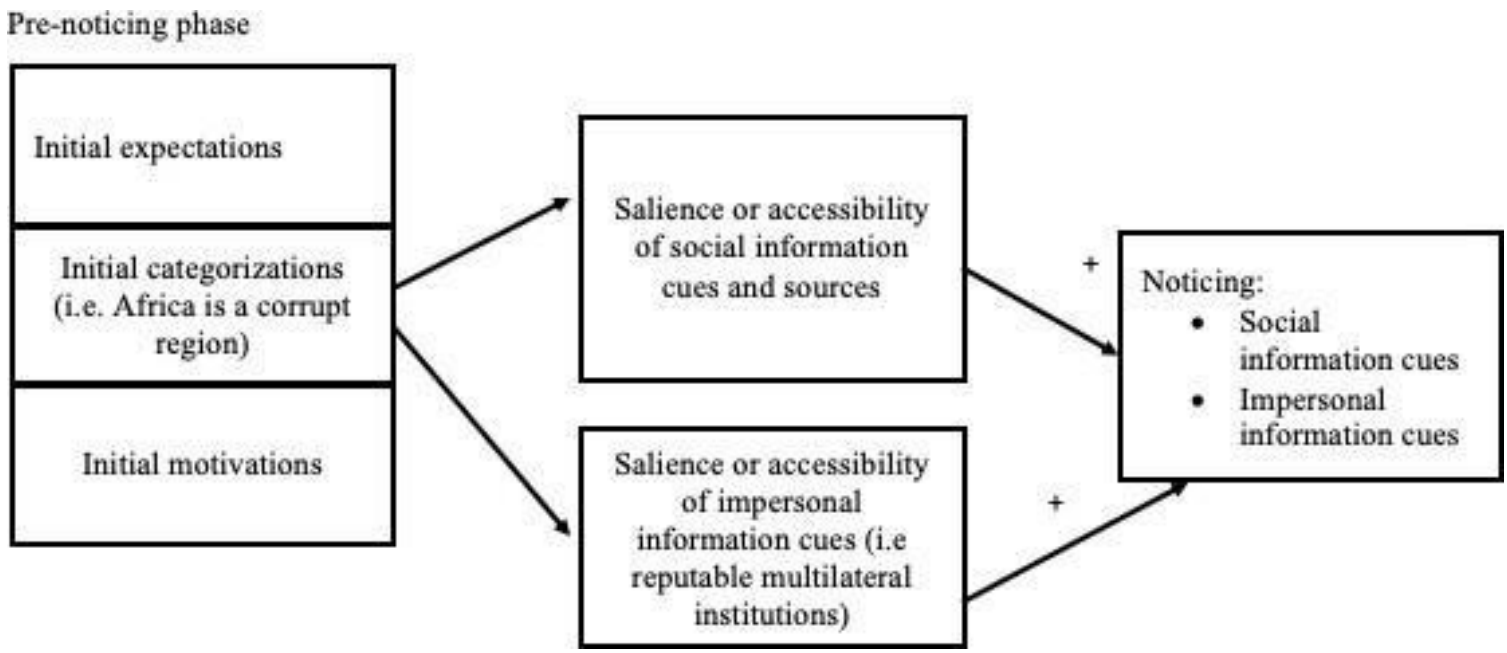

The conceptual model shown in Figure 3 summarizes the attention processes that senior managers engage in when recognizing opportunities in institutionally distant markets like SSA. Senior managers engage in the pre-noticing phase, which impacts the salience or accessibility of social information and impersonal information cues. This then impacts the noticing phase (Ocasio, 1997). As shown in Table 5, the sense-making period typically takes place during the pre-noticing phase and depends on the salience and accessibility of the information. The perceive value and quality of the opportunity makes senior managers notice the opportunities in the said market.

To answer the questions raised at the beginning of this study, insights from the research answers the questions raised in the following ways 1) That senior managers' attention processes comprise their initial expectations, initial categorizations and initial motivations which their ability to attend to information from sources hence impacting opportunity recognition 2) the quality and value of the opportunity, senior managers translate such opportunities into business activities based on the categorizations and mental expectations they have of the market. 


\section{CHAPTER 6 IMPLICATIONS AND LIMITATIONS}

This thesis identifies patterns and differences in how senior decision makers recognize opportunities in distant markets like the SSA market. Chapter 5 discusses how senior managers bring their mental models and schemas to bear on their attention process when seeking opportunities in SSA markets. These observations are relevant to the theoretical understanding of senior managers and how they attend to and pursue opportunities for global expansion. It also has implications for business practitioners and policymakers who are interested in improving trade relations between Canada and SSA.

\subsection{Theoretical Implications}

In clarifying the gaps in IB theories and answering the questions laid out at the beginning this thesis, this study has contributed to the field of IB by outlining an empirical validation for how senior managers recognize opportunities in distant markets. In summary, the theoretical implications include 1) ways in which senior managers attend to their pre-existing mental heuristic, 2) the accessibility and salience of networks to override categorizations of the market, 3) the importance and impact of networks and sources on senior managers' attention and their opportunity recognition process and 4) the attention pathways and processes of senior managers that account for which markets are excluded or included in global expansion. Taken together, these insights support a nuanced attention-based perspective of senior managers' roles in the opportunity recognition of internationalizing firms in the context of institutionally distant foreign markets. 


\subsection{Practical Implications}

This study positions the SSA market as a high potential market for Canadian business owners in which to capture opportunity. Senior managers of Canadian businesses must be ready to recognize the pre-exiting mental models they bring when approaching the SSA market and clarify these mental models in light of the realities of internationalizing in that market. Also, senior managers should seek diverse networks to help make sense of opportunities in distant markets and prevent them from overlooking opportunities.

As mentioned earlier, senior managers' attention is limited because so many things are vying for it. Therefore, this bounded rationality (i.e an individual's ability to process, store and retrieve information is limited) reveals that in decision-making the rationality of individuals is limited by information accessibility, time constraints and the cognitive limitation of their mind. Hence, senior managers should create a diverse management team and workforce to help extend their limited attention capacity. This would increase the range of information they could receive that would, in turn, impact their ability to recognize opportunities for internationalization.

Lastly, this thesis reveals that psychic distance is a matter of perception that can be managed by awareness of pre-existing mental models and reconciling that with information from networks and other sources. With Canada being a diverse and multicultural country, nations are closer than we think, but decision-makers must be willing to lay aside preconceived biases about a particular market to attend properly to opportunities coming from that market.

\subsection{Policy Implications}

Policymakers in Canada and other developed countries have shown interest in encouraging companies to seek international business opportunities outside of their traditional markets. Discussions on diversifying trade into SSA should be encouraged, and Canadian firms should 
actively seek business opportunities in SSA. Government policies regarding SSA should extend beyond foreign aid and focus on increased trade and business activities.

With the Canadian economy being popularly known as a risk-averse economy, this thesis challenges Canadian senior managers to be proactive in recognizing opportunities in the SSA market, given the opportunities available to Canadian companies to expand their international activities and the relatively strong growth performance of the SSA market. Policymakers need to further encourage business leaders by creating policies that enhance business relations between Canada and SSA.

\subsection{Limitations and Directions for Future Research}

Although this study looks at internationalization from a broad perspective, it only covers a specific region, that is, the SSA market. Other topics to be studied include opportunity recognition in other distant regions while still exploring the opportunity recognition process of senior managers.

Because the interview questions required participants to think about when they first became aware of the African market, the possibility of recollection bias in this thesis exists. Participants may have omitted information that could have brought more clarity and possibly extended the scope of the research.

Since this study deployed a purposeful sampling of a limited number of small and medium-sized firms, this study remains generalizable to larger firms irrespective of firm size and industry. This is because the study explores the attention process of senior managers, which is constant across firms that vary in size and industry.

Given the worthiness of a master's thesis, many, if not all companies in this study were more hesitant to provide sensitive information on financial performance, networks both at home 
and abroad and opportunities realized than is represented in the collected data. Future studies could focus on the following: First, the specific limitation of investigating the influence of multilateral agencies on opportunity recognition in the internationalization process. Second, the various types of information senior managers generally seek when making internationalization decisions as the thesis reveals that which networks senior managers reached out to depended on the type of information they sought. Further studies could empirically study this relationship on a larger scale. Third, it would be fruitful to conduct quantitative analyses of how senior managers' biases impact their attention processes. Future studies could explore the relationship between cognition and opportunity recognition in a way that a qualitative study does not capture. Fourth, further studies could expand on how organizational structure and chain of command impacts how senior managers attend to and recognize opportunities in distant markets. Also, a comparative study of the role of immigrant-owned companies in global expansion and opportunity recognition in distant markets would be valuable. Finally, future studies could look at opportunity recognition from the perspective of a developing country to a developed country (i.e., SSA to Canada). 


\section{CHAPTER 7 CONCLUSION}

This thesis has sought to answer two research questions: 1) How do senior managers' attention patterns enable opportunity recognition in SSA countries? 2) How do senior managers collect useful information from networks and translate it into a business opportunity in SSA countries? I applied a case study method, with in-depth interviews, to assess the attention patterns of senior business managers in Canada. Based on an analysis of the interviews, I have provided findings and insights that build on and extend an attention-based perspective of the opportunity recognition process in institutionally distant foreign markets. This perspective not only deepens our understanding of why senior managers from Western firms overlook or ignore opportunities in attractive African countries, but also offers insight into how they might better attend to such opportunities when expanding their firms globally. 


\section{Appendix A Interview Guide}
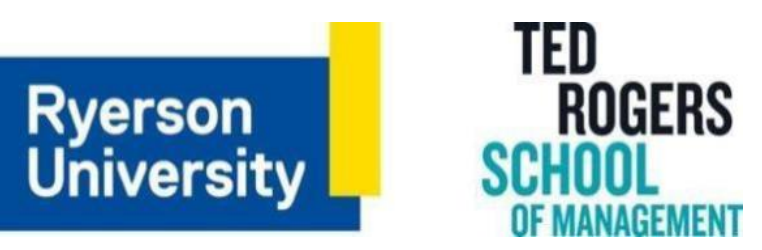

\section{Semi-Structured Interview Guide}

\begin{tabular}{|c|c|c|}
\hline Activity & Comments & Approx. Time \\
\hline 1- Introduction & $\begin{array}{l}\text { Confirmation of consent. } \\
\text { Brief the participant. } \\
\text { Introduce self. } \\
\text { Explain goals of the interview. Review } \\
\text { interview method, use of data, } \\
\text { confidentiality, etc. }\end{array}$ & $5 \mathrm{mins}$ \\
\hline $\begin{array}{l}\text { 2- Background/structured } \\
\text { questions }\end{array}$ & See below & $20-30 \mathrm{mins}$ \\
\hline 3- Open-ended questions & $\begin{array}{l}\text { Open-ended questions about strategies } \\
\text { used by the participant's business, for } \\
\text { example, the participant could share a } \\
\text { time where a strategy has been } \\
\text { effective or ineffective. }\end{array}$ & $30-40$ mins \\
\hline 4- Closing comments & $\begin{array}{l}\text { Collection of paperwork and closing } \\
\text { comments. }\end{array}$ & $5 \mathrm{mins}$ \\
\hline
\end{tabular}

\section{RESEARCH QUESTIONS:}

The purpose of this research is to investigate the process of opportunity recognition in multinational corporations that operate in institutionally and psychically distant countries, such as SSA countries. Specifically, this research will look at how the attention allocation patterns of senior management teams might be related to the perceived quality of opportunities in SSA. I will address the following questions:

a) How do top management team attention patterns enable opportunity recognition in SSA countries? 
b) How do top management teams (TMTs) collect useful information from networks to translate it into a business opportunity worth exploring in SSA countries?

\section{PART I}

\section{FILTER QUESTIONS:}

\section{Please answer the following questions below:}

a. Are you part of your company's senior executive team that handles international business development?

b. Is your company incorporated and headquartered in Canada?

c. Does your company currently have business operations in one or more SSA countries, or actively taking steps to do so in less than 5 years? If so, which African country (or countries)?

d. What type of business operations do you currently have or intend to have in the stated country (or countries)?

For example: exporting: sell goods or services for customers in Africa; foreign direct investment i.e., build a new plant, facility or store (with 100 percent ownership): cross-border merger and acquisition (M\&A)- i.e., merged with, or acquire a local company in the target country; International joint venture: create a joint venture with a local partner; other- please specify.

\section{BACKGROUND QUESTIONS}

Please answer the following questions about your organization:

a. In which year was your company established?

b. Size of company (number of full-time and part-time employees)? 
c. What is the annual revenue growth in the past 3 years?

d. What is the annual employment growth in the past 3 years?

e. What company's resources, capabilities, routines and rules are helpful for international expansion in general, and particularly in SSA?

\section{Please answer the following questions about your senior management team:}

a) What is the size of the senior management team?

b) How long is a senior management team member tenure?

c) What is the educational background of team members? (business, STEM, law etc.)

d) What type of prior industry experience do members of the senior management team have?

e) Does anyone on your senior management team have international experience in Africa? (work/study experience)?

f) Are there specific functional roles within the senior management team? If so, please list them.

g) Please list the names of people within the company with whom you discuss business opportunities related to SSA.

h) Please make a list of sources/contacts you reach out to when you want to learn about new developments in SSA.

\section{PART II}

\section{PROCESS OF CREATING AND DISCOVERING OPPORTUNITY}

\section{Structured Questions:}

On a scale of one to seven, with one being (Strongly Disagree) to seven (Strongly Agree) please answer the following questions on your information sources in SSA. 
a) I tried to make myself aware of my key networks/contacts who have knowledge on business opportunities in SSA. (Scanning)

b) I made effort to ask for referrals from my key networks/contacts to get new contacts who have knowledge on business opportunities in SSA. (Network broadening)

c) I tried to make myself aware of the latest development and information related to SSA. (Searching/Noticing).

d) I tried to make myself aware of information that my key contacts have on business opportunities in SSA. (Noticing).

e) I tried to think about how knowledge and information from key sources/contacts provided on SSA could be linked to my pre-existing views on business opportunities in SSA (Encoding).

f) I made efforts to interpret information received from sources/contacts about recent developments in SSA. (Interpreting).

g) I focused my time and effort on clarifying specifics to gain more details about knowledge from new sources/contacts on SSA. (focusing time and attention)

\section{Open ended questions:}

a) Given your company's (intended) business operations in SSA, think back to the time before you considered SSA. Walk me through the process of when you became aware/first thought of SSA as a potential place to do business

a. Did this awareness come about as a result of an in-house corporate development strategy or was it a senior team initiative? 
b. Did feedback from another senior executive with prior experience in Africa influence how things unfolded? If so how?

c. Did you involve anyone outside of the senior management team?

d. How did you select SSA? Did you consider other locations?

b) Could you describe a time when you received information about an opportunity in SSA market that sparked your interest in the region?

a. How did this information come about? was it from a single or several sources?

b. How did you decide on what source of information/contact to further investigate for the business opportunity?

c. How did you flesh out this information among the senior management team?

d. How did you go about actively finding out more details about the information received?

e. How did you make sense of the information based on your pre-existing views of SSA?

c) Could you think back to the people with whom you discussed/reached out to for business opportunities in SSA:

a. How did you go about developing your personal networks to gain the information on business opportunity in SSA?

b. In a situation where no one in your sphere of influence has the information on SSA, whom/what did you seek out for information?

c. How would you describe your relationship with your networks?

\section{Perceived Value/quality of the recognized business opportunity in SSA:}


For the currently recognized, but unexploited opportunity in Sub-Sahara Africa, please rate its potential level of impact on a scale of 1 to $10(1=$ "no impact", $10=$ "high impact") on the company's performance, measured in terms of:

1) Financial Indicators:

a. Profitability [Potential level of impact___]

b. Growth in terms of (i.) revenue or sales [Potential level of impact__]; (ii.) Customer base [Potential level of impact___].

2) Non-Financial Indicators:

a. International scale (i.e., percentage of total sales that comes from foreign sales) [Potential level of impact___]

b. International scope (i.e., number of foreign markets or regions in which the company operates) [Potential level of impact__]. 


\section{Appendix B Code Book}

\begin{tabular}{|c|c|}
\hline NAME & DESCRIPTION \\
\hline Basic info on the company & $\begin{array}{l}\text { Basic information about the case company, such as age, } \\
\text { size, and so forth }\end{array}$ \\
\hline age of the company & Age of the case company \\
\hline Other info & $\begin{array}{l}\text { Notable information other than age, size, and } \\
\text { performance of the case company }\end{array}$ \\
\hline Top management team & $\begin{array}{l}\text { Coded if the participant is part of a top management } \\
\text { team, which includes decision-makers }\end{array}$ \\
\hline Networks & $\begin{array}{l}\text { The contacts and sources that participants reach out to } \\
\text { for information on the international business. }\end{array}$ \\
\hline Sub-Saharan Africa & $\begin{array}{l}\text { Coded when participant mentions country of operation } \\
\text { in sub-Saharan Africa region }\end{array}$ \\
\hline Scanning & $\begin{array}{l}\text { Looking at different opportunities in the international } \\
\text { market scene }\end{array}$ \\
\hline Network broadening & $\begin{array}{l}\text { Broadening the network and extending it beyond current } \\
\text { networks }\end{array}$ \\
\hline Networks & The people senior managers reach out to for information. \\
\hline Noticing & The process of becoming aware of information \\
\hline Encoding & The process of making sense of information \\
\hline Product/Service & $\begin{array}{l}\text { Product and services which case companies offer to the } \\
\text { market }\end{array}$ \\
\hline Focusing time and attention & $\begin{array}{l}\text { The process of taking time to clarify and gain more } \\
\text { details on information received }\end{array}$ \\
\hline Size-number of employees & $\begin{array}{l}\text { The number of full-time employees measures the size of } \\
\text { the case company }\end{array}$ \\
\hline $\begin{array}{l}\text { Size-number of top management } \\
\text { team }\end{array}$ & $\begin{array}{l}\text { The number of management team involved in } \\
\text { internationalization decisions }\end{array}$ \\
\hline Business operations & $\begin{array}{l}\text { The type of business operation run by the case } \\
\text { company., e.g., joint venture, M\&A }\end{array}$ \\
\hline $\begin{array}{l}\text { Perceived value/quality of } \\
\text { business opportunity }\end{array}$ & $\begin{array}{l}\text { The quality of the business opportunity that has been } \\
\text { recognized by case company }\end{array}$ \\
\hline Previous experience & $\begin{array}{l}\text { Previous experience in Africa of senior management } \\
\text { team }\end{array}$ \\
\hline Opportunity recognition & $\begin{array}{l}\text { The supposed opportunity in the market recognized by } \\
\text { case company }\end{array}$ \\
\hline Referrals & Eternal contacts gotten from personal contacts \\
\hline Reason for internationalization & Reason for internationalization into a new market \\
\hline Revenue & Annual revenue and cash flow \\
\hline
\end{tabular}




\begin{tabular}{|l|l|}
\hline Foreign markets & Any market outside of the case company's own country \\
\hline Education & Education background of management team \\
\hline Ppportunity SSA & $\begin{array}{l}\text { The opportunity to be gained from successful } \\
\text { internationalization }\end{array}$ \\
\hline Time spent building networks & $\begin{array}{l}\text { Amount of time and effort spent building networks and } \\
\text { developing relationships }\end{array}$ \\
\hline Personal connections & $\begin{array}{l}\text { Personal connections that provide information about } \\
\text { internationalization }\end{array}$ \\
\hline Top management team & $\begin{array}{l}\text { Top team in the organization that is responsible for } \\
\text { important decisions }\end{array}$ \\
\hline Reasons for internationalization & $\begin{array}{l}\text { Coded when participants mention reasons for expanding } \\
\text { outside of market }\end{array}$ \\
\hline Initial entry & First entry into the SSA market \\
\hline Ease of market entry & $\begin{array}{l}\text { The ease of entering into the sub-Saharan Africa market, } \\
\text { political stability, market size, etc. }\end{array}$ \\
\hline Disparate information & $\begin{array}{l}\text { Information that is conflicting and dissimilar to other } \\
\text { information }\end{array}$ \\
\hline Multilateral agencies & $\begin{array}{l}\text { Agencies that provide market information such as trade } \\
\text { commissioner, etc. }\end{array}$ \\
\hline Work experience & $\begin{array}{l}\text { Experience of work in companies such as multinational } \\
\text { corporations }\end{array}$ \\
\hline Firm specific advantages & $\begin{array}{l}\text { Advantages that are peculiar to a firm, e.g., immigrant } \\
\text { ownership, etc. }\end{array}$ \\
\hline Internationalization experience & $\begin{array}{l}\text { Experience in extending company activities beyond } \\
\text { existing markets }\end{array}$ \\
\hline Internationalization & $\begin{array}{l}\text { Thpanding business activities outside of home market } \\
\text { makers bring to situations they encounter }\end{array}$ \\
\hline Preconceived bias &
\end{tabular}




\section{REFERENCES}

Aharoni, Y. (1966). The foreign investment decision process. Division of Research, Graduate School of Business Administration, Harvard University.

Aharoni, Y., Tihanyi, L., \& Connelly, B. L. (2011). Managerial decision-making in international business: A forty-five-year retrospective. Journal of World Business, 46(2), 135-142.

Amason, A. C. (1996). Distinguishing the effects of functional and dysfunctional conflict on strategic decision making: Resolving a paradox for top management teams. Academy of Management Journal, 39(1), 123-148.

Ardichvili, A., Cardozo, R., \& Ray, S. (2003). A theory of entrepreneurial opportunity identification and development. Journal of Business Venturing, 18(1), 105-123.

Athanassiou, N., \& Nigh, D. (1999). The impact of US company internationalization on top management team advice networks: A tacit knowledge perspective. Strategic Management Journal, 20(1), 83-92.

Barney, J. (1991). Firm resources and sustained competitive advantage. Journal of Management, 17(1), 99-120.

Baron, R. A., \& Ensley, M. D. (2006). Opportunity recognition as the detection of meaningful patterns: Evidence from comparisons of novice and experienced entrepreneurs. Management Science, 52(9), 1331-1344.

Berger, P. L., Luckmann, T., \& Zifonun, D. (1967). The social construction of reality: A treatise in the sociology of knowledge. Anchor. 
Berman, J. (2016, April 12). Meet the tech companies creating opportunity in Africa. Harvard Business Review. https://hbr.org/2016/04/meet-the-tech-companies-creating-opportunityin-africa

Beugelsdijk, S., Ambos, B., \& Nell, P. C. (2018). Conceptualizing and measuring distance in international business research: Recurring questions and best practice guidelines. Journal of International Business Studies, 49, 1113-1117. https://doi.org/10.1057/s41267-0180182-4

Birkinshaw, J., Brannen, M. Y., \& Tung, R. L. (2011). From a distance and generalizable to up close and grounded: Reclaiming a place for qualitative methods in international business research.

Black, D. R., Thérien, J.-P., \& Clark, A. (1996). Moving with the crowd: Canadian aid to Africa. International Journal, 51(2), 259-286. https://doi.org/10.2307/40203783

Brewer, P. A. (2007). Operationalizing psychic distance: A revised approach. Journal of International Marketing, 15(1), 44-66.

Brouthers, K. D., Brouthers, L. E., \& Werner, S. (1996). Dunning's eclectic theory and the smaller firm: The impact of ownership and locational advantages on the choice of entrymodes in the computer software industry. International Business Review, 5(4), 377-394.

Brouthers, K. D., Geisser, K. D., \& Rothlauf, F. (2016). Explaining the internationalization of ibusiness firms. Journal of International Business Studies, 47(5), 513-534.

Brouthers, K. D., \& Hennart, J. F. (2007). Boundaries of the firm: Insights from international entry mode research. Journal of Management, 33(3), 395-425.

Buckley, P., \& Casson, M. (2009). The multinational enterprise revisited: The essential Buckley and Casson. Springer. 
Burt, R. S. (1992). Structural holes: The social structure of competition. Harvard University Press.

Caligiuri, P., Lazarova, M., \& Zehetbauer, S. (2004). Top managers' national diversity and boundary spanning. Journal of Management Development, 23(9), 849-859. https://doi.org/10.1108/02621710410558459

Canadian International Development Platform. (2019). Canada's foreign aid. https://cidpnsi.ca/canadas-foreign-aid-2012-2/

Chandra, Y., Styles, C., \& Wilkinson, I. F. (2012). An opportunity-based view of rapid internationalization. Journal of International Marketing, 20(1), 74-102.

Choo, C. W. (1996). The knowing organization: How organizations use information to construct meaning, create knowledge and make decisions. International Journal of Information Management, 16(5), 329-340.

Collinson, S., \& Houlden, J. (2005). Decision-making and market orientation in the internationalization process of small and medium-sized enterprises. Management International Review, 45(4), 413-436.

Coviello, N. E., \& Munro, H. J. (1995). Growing the entrepreneurial firm. European Journal of Marketing, 29(7), 49-61.

Coviello, N. E., \& Munro, H. J. (1997). Network relationships and the internationalisation process of small software firms. International Business Review, 6(4), 361-386.

Cyert, R. M., \& March, J. G. (1963). A behavioral theory of the firm. University of Illinois at Urbana-Champaign's Academy for Entrepreneurial Leadership Historical Research Reference in Entrepreneurship. https://ssrn.com/abstract=1496208

Davenport, T. H., \& Beck, J. C. (2001). The attention economy. Ubiquity 2001(May). https://doi.org/10.1145/376625.376626 
Davenport, T. H., \& Völpel, S. C. (2001). The rise of knowledge towards attention management. Journal of Knowledge Management, 5(3), 212-222.

de Haldevang, M. (2016, September 2). Why do we still use the term "sub-Saharan Africa"? QuartzAfrica. https://qz.com/africa/770350/why-do-we-still-say-subsaharan-africa/

DiMaggio, P. J. (1991). Introduction. In W. W. Powell \& P. J. DiMaggio (Eds.), The new institutionalism in organizational analysis (pp. 1-38). University of Chicago Press.

DiMaggio, P. J., \& Powell, W. W. (1983). The iron cage revisited: Institutional isomorphism and collective rationality in organizational fields. American Sociological Review, 48(2), 147160.

Dow, D., \& Karunaratna, A. (2006). Developing a multidimensional instrument to measure psychic distance stimuli. Journal of International Business Studies, 37(5), 578-602.

Dunning, J. H. (1988). The theory of international production. The International Trade Journal, $3(1), 21-66$.

Dunning, J. H. (1980). Toward an eclectic theory of international production: Some empirical tests. Journal of international business studies, 11(1), 9-31.

Dunning, J. H. (1998). Location and the multinational enterprise: A neglected factor? Journal of International Business Studies, 29(1), 45-66.

Dunning, J. H. (2000). The eclectic paradigm as an envelop for economic and business theories of MNE activity. International Business Review, 9(2), 163-190.

Dunning, J. H., \& Buckley, P. J. (1977). International production and alternative models of trade. Manchester School of Economics and Social Studies, 45(4), 392-403.

Eden, L., \& Miller, S. R. (2004). Distance matters: Liability of foreignness, institutional distance and ownership strategy. Advances in International Management, 16(4), 187-221. 
Eggers, J. P., \& Kaplan, S. (2013). Cognition and capabilities: A multi-level perspective. Academy of Management Annals, 7(1), 295-340.

Eisenhardt, K. M. (1989). Building theories from case study research. The Academy of Management Review, 14, 532-550.

Eisenhardt, K. M., \& Graebner, M. E. (2007). Theory building from cases: Opportunities and challenges. Academy of Management Journal, 50(1), 25-32.

Eriksson, K., Johanson, J., Majkgård, A., \& Sharma, D. D. (2015). Experiential knowledge and cost in the internationalization process. In U. Holm, M. Forsgren, \& J. Johanson (Eds.), Knowledge, networks and power (pp. 41-63). Palgrave Macmillan.

Export Development Canada. (n.d.). About Us. Government of Canada. https://www.edc.ca/en/about-us.html

Figueira-de-Lemos, F., \& Hadjikhani, A. (2014). Internationalization processes in stable and unstable market conditions: Towards a model of commitment decisions in dynamic environments. Journal of World Business, 49(3), 332-349.

Fiske, S. T., \& Taylor, S. E. (2013). Social cognition: From brains to culture. Sage.

Gioia, D. A., Corley, K. G., \& Hamilton, A. L. (2013). Seeking qualitative rigor in inductive research: Notes on the Gioia methodology. Organizational Research Methods, 16(1), 1531.

Global Affairs Canada. (2019). Canada's state of trade. Government of Canada. https://www.international.gc.ca/gac-amc/assets/pdfs/publications/State-of-Trade2019_eng.pdf

Global Affairs Canada. (2020). Canada and Sub-Saharan Africa. Government of Canada. https://www.international.gc.ca/world-monde/international_relationsrelations_internationales/africa-afrique/index.aspx?lang=eng 
Gordon, S. (2018, April 3). Into Africa: Canadian firms jump on opportunity. Globe and Mail. https://www.theglobeandmail.com/report-on-business/small-business/going-global/intoafrica-canadian-firms-jump-on-opportunity/article535446/

Greenwood, R., Raynard, M., Kodeih, F., Micelotta, E. R., \& Lounsbury, M. (2011). Institutional complexity and organizational responses. Academy of Management Annals, 5(1), 317371.

Guest, G., Bunce, A., \& Johnson, L. (2006). How many interviews are enough? An experiment with data saturation and variability. Field Methods, 18(1), 59-82.

Guler, I., \& Guillén, M. F. (2010). Home country networks and foreign expansion: Evidence from the venture capital industry. Academy of Management Journal, 53(2), 390-410.

Harveston, P. D., Kedia, B. L., \& Davis, P. S. (2000). Internationalization of born global and gradual globalizing firms: The impact of the manager. Journal of Competitiveness Studies, 8(1), 92.

Hennart, J. F. (2009). Down with MNE-centric theories! Market entry and expansion as the bundling of MNE and local assets. Journal of International Business Studies, 40(9), 1432-1454.

Herstad, S. J., Aslesen, H. W., \& Ebersberger, B. (2014). On industrial knowledge bases, commercial opportunities and global innovation network linkages. Research Policy, 43(3), 495-504.

Hoffman, A. J., \& Ocasio, W. (2001). Not all events are attended equally: Toward a middlerange theory of industry attention to external events. Organization Science, 12(4), 414434. 
Hohenthal, J., Johanson, J., \& Johanson, M. (2015). Network knowledge and businessrelationship value in the foreign market. In M. Forsgren, U. Holm, \& J. Johanson (Eds.), Knowledge, networks and power (pp. 187-224). Palgrave Macmillan.

Hood, N., \& Young, S. (1979). The economics of multinational enterprise. Longman.

International Monetary Fund (IMF). (2019). Regional economic outlook: SSA: Navigating uncertainty.

Retrieved

from https://www.imf.org/en/Publications/REO/SSA/Issues/2019/10/01/sreo1019

Johanson, J., \& Vahlne, J. E. (2009). The Uppsala internationalization process model revisited: From liability of foreignness to liability of outsidership. Journal of international business studies, 40(9), 1411-1431.

Javalgi, R. R. G., \& Todd, P. R. (2011). Entrepreneurial orientation, management commitment, and human capital: The internationalization of SMEs in India. Journal of Business Research, 64(9), 1004-1010.

Johanson, J., \& Vahlne, J. E. (1977). The internationalization process of the firm-A model of knowledge development and increasing foreign market commitments. Journal of International Business Studies, 8(1), 23-32.

Johanson, J., \& Vahlne, J. E. (1990). The mechanism of internationalization. International Marketing Review, 7(4). https://doi.org/10.1108/02651339010137414

Johanson, J., \& Vahlne, J. E. (2003). Business relationship learning and commitment in the internationalization process. Journal of International Entrepreneurship, 1(1), 83-101.

Johanson, J., \& Vahlne, J. E. (2006). Commitment and opportunity development in the internationalization process: A note on the Uppsala internationalization process model. Management International Review, 46(2), 165-178. 
Johanson, J., \& Vahlne, J. E. (2009). The Uppsala internationalization process model revisited: From liability of foreignness to liability of outsidership. Journal of International Business Studies, 40(9), 1411-1431.

Kielburger, C. (2017, July 11). Global voices: Why Canada should do business with Africa. O Canada. https://o.canada.com/life/global-voices-why-canada-should-do-business-withafrica

Knight, G. A., \& Cavusgil, S. T. (2004). Innovation, organizational capabilities, and the bornglobal firm. Journal of International Business Studies, 35(2), 124-141.

Kogut, B., \& Singh, H. (1988). The effect of national culture on the choice of entry mode. Journal of International Business Studies, 19(3), 411-432.

Kogut, B., \& Zander, U. (2003). Knowledge of the firm and the evolutionary theory of the multinational corporation. Journal of International Business Studies, 34(6), 516-529.

Kontinen, T., \& Ojala, A. (2010). Internationalization pathways of family SMEs: Psychic distance as a focal point. Journal of Small Business and Enterprise Development, 17(3), 437-454. https://doi.org/10.1108/14626001011068725

Kontinen, T., \& Ojala, A. (2011). Network ties in the international opportunity recognition of family SMEs. International Business Review, 20(4), 440-453.

Kriz, A., \& Welch, C. (2018). Innovation and internationalisation processes of firms with newto-the-world technologies. Journal of International Business Studies, 49(4), 496-522.

Kumar, V., Mudambi, R., \& Gray, S. (2013). Internationalization, innovation and institutions: The three I's underpinning the competitiveness of emerging market firms. Journal of International Management, 19(3), 203-206. 
Leke, A., Chironga, M., \& Desvaux, G. (2018). Africa's overlooked business revolution. Mckinsey and company. https://www.mckinsey.com/featured-insights/middle-east-andafrica/africas-overlooked-business-revolution

Levy, O. (2005). The influence of top management team attention patterns on global strategic posture of firms. Journal of Organizational Behavior: The International Journal of Industrial, Occupational and Organizational Psychology and Behavior, 26(7), 797-819.

Levy, O., Beechler, S., Taylor, S., \& Boyacigiller, N. A. (2007). What we talk about when we talk about "global mindset": Managerial cognition in multinational corporations. Journal of International Business Studies, 38(2), 231-258.

Lew, Y. K., Sinkovics, R. R., \& Kuivalainen, O. (2013). Upstream internationalization process: Roles of social capital in creating exploratory capability and market performance. International Business Review, 22(6), 1101-1120.

Loane, S., Bell, J. D., \& McNaughton, R. (2007). A cross-national study on the impact of management teams on the rapid internationalization of small firms. Journal of World Business, 42(4), 489-504.

Madhok, A. (1997). Cost, value and foreign market entry mode: The transaction and the firm. Strategic Management Journal, 18(1), 39-61.

Magnani, G., Zucchella, A., \& Floriani, D. E. (2018). The logic behind foreign market selection: Objective distance dimensions vs. strategic objectives and psychic distance. International Business Review, 27(1), 1-20.

Maitland, E., \& Sammartino, A. (2015). Managerial cognition and internationalization. Journal of International Business Studies, 46(7), 733-760.

Maitlis, S., \& Christianson, M. (2014). Sensemaking in organizations: Taking stock and moving forward. Academy of Management Annals, 8(1), 57-125. 
Melin, L. (1992). Internationalization as a strategy process. Strategic Management Journal, 13(S2), 99-118.

Meyer, J. W., \& Rowan, B. (1977). Institutionalized organizations: Formal structure as myth and ceremony. American Journal of Sociology, 83(2), 340-363.

Monga, V. (2018, September 3). U.S. growth powers Canadian banks. Wall Street Journal. https://www.wsj.com/articles/u-s-growth-powers-canadian-banks-1535983200

Monks, K. (2017, February 24). M-Pesa: Kenya's mobile success story turns 10. CNN. https://www.cnn.com/2017/02/21/africa/mpesa-10th-anniversary/index.html

Moore, D. (2019, October 28). Post NAFTA post-mortem: Is Canada better off under the new, less catchy CUSMA. Globe and Mail. https://www.theglobeandmail.com/featuredreports/article-post-nafta-post-mortem-is-canada-better-off-under-the-new-less/

Musteen, M., Francis, J., \& Datta, D. K. (2010). The influence of international networks on internationalization speed and performance: A study of Czech SMEs. Journal of World Business, 45(3), 197-205.

National Security and Defence. (2019). Operation Presence. Government of Canada. https://www.canada.ca/en/department-national-defence/services/operations/militaryoperations/current-operations/op-presence.html

Nielsen, B. B., \& Nielsen, S. (2013). Top management team nationality diversity and firm performance: A multilevel study. Strategic Management Journal, 34(3), 373-382.

Nonaka, L., Takeuchi, H., \& Umemoto, K. (1996). A theory of organizational knowledge creation. International Journal of Technology Management, 11(7-8), 833-845.

Ocasio, W. (1997). Towards an attention-based view of the firm. Strategic Management Journal, 18(S1), 187-206.

Ocasio, W. (2011). Attention to attention. Organization Science, 22(5), 1286-1296. 
Odlin, D., \& Benson-Rea, M. (2017). Competing on the edge: Implications of network position for internationalizing small and medium-sized enterprises. International Business Review, 26(4), 736-748.

Ojala, A. (2015). Geographic, cultural, and psychic distance to foreign markets in the context of small and new ventures. International Business Review, 24(5), 825-835.

Oviatt, B. M., \& McDougall, P. P. (1994). Toward a theory of international new ventures. Journal of International Business Studies, 25(1), 45-64.

Owen-Smith, J., \& Powell, W. W. (2004). Knowledge networks as channels and conduits: The effects of spillovers in the Boston biotechnology community. Organization Science, $15(1), 5-21$.

Ozgen, E., \& Baron, R. A. (2007). Social sources of information in opportunity recognition: Effects of mentors, industry networks, and professional forums. Journal of Business Venturing, 22(2), 174-192.

Peng, M. W., Sun, S. L., Pinkham, B., \& Chen, H. (2009). The institution-based view as a third leg for a strategy tripod. Academy of Management Perspectives, 23(3), 63-81.

Penrose, R. (1996). On gravity's role in quantum state reduction. General relativity and gravitation, 28(5), 581-600.

Pettigrew, A. M., Woodman, R. W., \& Cameron, K. S. (2001). Studying organizational change and development: Challenges for future research. Academy of Management Journal, 44(4), 697-713.

Phillips, N., \& Tracey, P. (2007). Opportunity recognition, entrepreneurial capabilities and bricolage: Connecting institutional theory and entrepreneurship in strategic organization. Strategic Organization, 5(3), 313-320. 
Pothukuchi, V., Damanpour, F., Choi, J., Chen, C. C., \& Park, S. H. (2002). National and organizational culture differences and international joint venture performance. Journal of International Business Studies, 33(2), 243-265.

Price, J. M. C. (2010). Coding: Open coding. In A. Mills, G. Durepos, \& E. Wiebe (Eds.), Encyclopedia of case study research. 2455 Teller Road, Thousand Oaks California 91320 United States: SAGE Publications, Inc.

Reeb, D., Sakakibara, M., \& Mahmood, I. P. (2012). From the editors: Endogeneity in international business research. Journal of International Business Studies, 43, 211-218.

Rhee, L., \& Leonardi, P. M. (2018). Which pathway to good ideas? An attention-based view of innovation in social networks. Strategic Management Journal, 39(4), 1188-1215.

Ridder, H. G. (2017). The theory contribution of case study research designs. Business Research, 10(2), 281-305.

Romney, A. K., Weller, S. C., \& Batchelder, W. H. (1986). Culture as consensus: A theory of culture and informant accuracy. American Anthropologist, 88(2), 313-338.

Rugman, A. M., Verbeke, A., \& Nguyen, Q. T. (2011). Fifty years of international business theory and beyond. Management International Review, 51(6), 755-786.

Sandberg, J., \& Tsoukas, H. (2015). Making sense of the sensemaking perspective: Its constituents, limitations, and opportunities for further development. Journal of Organizational Behavior, 36(S1), S6-S32.

Schellenberg, M., Harker, M. J., \& Jafari, A. (2018). International market entry mode-A systematic literature review. Journal of Strategic Marketing, 26(7), 601-627.

Schwenk, C. R. (1988). The cognitive perspective on strategic decision making. Journal of Management Studies, 25(1), 41-55. 
Schwens, C., Eiche, J., \& Kabst, R. (2011). The moderating impact of informal institutional distance and formal institutional risk on SME entry mode choice. Journal of Management Studies, 48(2), 330-351.

Scott, W. R. (2005). Institutional theory: Contributing to a theoretical research program. In K. G. Smith \& M. A. Hitt (Eds.) Great minds in management: The process of theory development (pp. 460-484). Oxford University Press.

Selznick, P. (1957). Leadership in administration. University of California Press.

Shenkar, O. (2012). Beyond cultural distance: Switching to a friction lens in the study of cultural differences. Journal of International Business Studies, 43(1), 12-17.

Siggelkow, N. (2007). Persuasion with case studies. Academy of Management Journal, 50(1), $20-24$.

Sigrist, B. (1999). Entrepreneurial opportunity recognition. In A presentation at the Annual UIC/AMA symposium at Marketing/Entrepreneurship Interface, Sofia-Antipolis, France.

Simons, T., Pelled, L. H., \& Smith, K. A. (1999). Making use of difference: Diversity, debate, and decision comprehensiveness in top management teams. Academy of Management Journal, 42(6), 662-673.

Statistics Canada. (2015). Activities of Canadian majority-owned affiliates abroad, expanded measures-Provisional estimates for reference year 2012. Government of Canada. https://www150.statcan.gc.ca/n1/pub/13-605-x/2015008/article/14225-eng.htm

Statistics Canada. (2019). Canadian majority-owned foreign affiliate sales by region. Government of Canada. https://www150.statcan.gc.ca/n1/daily-quotidien/190924/cga002-eng.htm

Stevenson, W. B., Pearce, J. L., \& Porter, L. W. (1985). The concept of "coalition" in organization theory and research. Academy of Management Review, 10(2), 256-268. 
Timmermans, S., \& Tavory, I. (2012). Theory construction in qualitative research: From grounded theory to abductive analysis. Sociological Theory, 30(3), 167-186.

Uzzi, B. (1996). The sources and consequences of embeddedness for the economic performance of organizations: The network effect. American Sociological Review, 61(4), 674-698.

Vahlne, J. E. (2020). Development of the Uppsala model of internationalization process: From internationalization to evolution. Global Strategy Journal, 10(2), 239-250. https://doi.org/10.1002/gsj.1375

Venkataraman, S. (2019). The distinctive domain of entrepreneurship research. In J. A. Katz \& A. C. Corbet (Eds.), Seminal ideas for the next twenty-five years of advances (pp. 5-20). Emerald. https://doi.org/10.1108/S1074-754020190000021009

Verbeke, A., \& Ciravegna, L. (2018). International entrepreneurship research versus international business research: A false dichotomy? Journal of International Business, 49, 387-394.

Webb, E., \& Weick, K. E. (1979). Unobtrusive measures in organizational theory: A reminder. Administrative Science Quarterly, 24(4), 650-659.

Weick, K. E. (1995). Sensemaking in organizations. Sage.

Why Africa? Building Canada's economic ties to the world's fastest-growing continent. (2020, March 2). Retrieved from https://thebusinesscouncil.ca/publications/why-africa-buildingcanadas-economic-ties-to-the-worlds-fastest-growing-continent/

World Competitiveness Ranking 2019. (n.d.). Retrieved from https://www.imd.org/wcc/worldcompetitiveness-center-rankings/world-competitiveness-ranking-2019/

World Bank. (2019). GDP per capita growth (annual \%). https://data.worldbank.org/indicator/NY.GDP.PCAP.KD.ZG?end=2018\&start=2001 
Xu, D., \& Shenkar, O. (2002). Note: Institutional distance and the multinational enterprise. Academy of Management Review, 27(4), 608-618.

Yavuz S. (2010). An attention-based view of internationalization: SMEs in emerging market economies (Order No. NR75686). Available from ProQuest Dissertations \& Theses Global. Retrieved from http://ezproxy.lib.ryerson.ca/login?url=https://search-proquestcom.ezproxy.lib.ryerson.ca/docview/879634537?accountid=13631

Yin, R. K. (2014). Case study research and applications: Design and methods. Sage.

Yiu, D., \& Makino, S. (2002). The choice between joint venture and wholly owned subsidiary: An institutional perspective. Organization Science, 13(6), 667-683.

Zaheer, S. (1995). Overcoming the liability of foreignness. Academy of Management Journal, $38(2), 341-363$.

Zahra, S. A., Korri, J. S., \& Yu, J. (2005). Cognition and international entrepreneurship: Implications for research on international opportunity recognition and exploitation. International Business Review, 14(2), 129-146.

Zhou, L., Wu, W. P., \& Luo, X. (2007). Internationalization and the performance of born-global SMEs: The mediating role of social networks. Journal of International Business Studies, $38(4), 673-690$. 